\title{
Metodologia Władysława Tatarkiewicza
}

\author{
Dominik Traczykowski \\ (Uniwersytet Kazimierza Wielkiego w Bydgoszczy)
}

\section{Wprowadzenie}

Władysław Tatarkiewicz (1886-1980) na gruncie nauki polskiej znany jest przede wszystkim z trzytomowej Historii filozofii, która przez wiele lat była klasycznym podręcznikiem do nauczania filozofii, a także z: Historii estetyki, Dziejów sześciu pojęć, oraz prac etycznych: O bezwzględności dobra, O szczęściu, O doskonałości, Dobro i oczywistość. Pisma etyczne, i estetycznych: O filozofii i sztuce, Skupienie i marzenie. Studia z zakresu estetyki.

Tatarkiewicz studiował na uniwersytetach w Warszawie, Zurychu, Berlinie, Paryżu i Marburgu ${ }^{1}$, gdzie uzyskał stopień doktora filozofii. Pomimo tego, że jak pisze:

Nie przesłuchałem nigdy porządnego kursu historii filozofii ani logiki, ani estetyki [...]. Chodziłem raczej na pasjonujące monograficzne wykłady Simmla. I jednocześnie uczęszczałem na wykłady z historii politycznej, archeologii klasycznej, historii sztuki, socjologii, psychologii eksperymentalnej, przeszedłem sumiennie kurs chemii, chodziłem nawet na wykłady wydziału medycznego: anatomii i psychiatrii. Było w tym znacznie więcej ciekawości niż programu, sensu konsekwentnego studiowania. Dość prędko zapomnia-

„Zajęć było mało: cztery razy na tydzień po południu były wykłady dwu profesorów: na wykłady te chodziłem, potem tylko na jeden, bo wykład Natorpa, monotonny, źle wygłaszany, nudził mnie; wybitnego uczonego wolałem czytać niż słuchać". W. Tatarkiewicz, Zapiski do autobiografii, w: T. i W. Tatarkiewiczowie, Wspomnienia, Państwowy Instytut Wydawniczy, Warszawa 1979, s. 125. 
łem prawie wszystko z tego, czego wówczas wysłuchałem - z wyjątkiem tego, czym się potem sam zajmowałem. Dziś byłbym złego mniemania o studencie, który by w ten sposób gospodarował swym czasem².

Końcowym etapem studiów Tatarkiewicza była publikacja rozprawy doktorskiej Układ pojęć w filozofii Arystotelesa ${ }^{3}$, która zdobyła uznanie w oczach ówczesnego światowego znawcy Arystotelesa - sir Davida Rossa, o czym jednak nie wiedział autor, skłonny na tym etapie życia do tego by:

[...] się dowiedzieć, jak pracują Polacy. Od razu przekonałem się, że pracują inaczej i lepiej; szkoła Twardowskiego uczyła właśnie, jak pracować naukowo. Było to niestety lato 1910; zamieszki ukraińskie spowodowały zawieszenie wykładów, zdążyłem być zaledwie na dwu wykładach i dwu ćwiczeniach mistrza. Nie pamiętam już, o czym była tam mowa, ale pamiętam metodę: odpowiadała mi bardziej niż innych zachodnich profesorów ${ }^{4}$.

Tatarkiewicza ocena stylu pracy naukowej w szkole Twardowskiego była zbieżna z poglądami zarówno członków szkoły, jak i dzisiejszych jej badaczy, wskazujących, że to właśnie metoda była czynnikiem spajającym Szkołę Lwowsko-Warszawską ${ }^{5}$.

Dla Tatarkiewicza zagadnienia metodologiczne rzadko stanowiły pole bezpośredniego namysłu, podejmował tę tematykę przede wszystkim w kontekście własnej pracy badawczej, stąd treści metodologiczne zawarte w niej explicite mają charakter fragmentaryczny, treści zaś implicite wymagają ekstrakcji - czego tutaj nie robię ${ }^{6}$. Stawiam sobie za cel rekonstrukcję poglądów Tatarkiewicza z zakresu

\section{Tamże, s. 123.}

3 „Tak się skończyły me studia: chaotyczne, przypadkowe, nie kierowane. Dowiedziałem się w ich toku, jak niektórzy filozofowie uprawiają naukę, ale żaden mi nie poradził, jak ja mam ją uprawiać; ani też nie podsunął tematu dalszej pracy”. W. Tatarkiewicz, Zapiski do autobiografii, dz. cyt., s. 125.

4 Tamże.

5 Szkoły Lwowsko-Warszawskiej nie spajała żadna doktryna filozoficzna, lecz wspólne przekonania metodologiczne obecne w postaci trzech postulatów: postulatu jasności wypowiedzi, postulatu należytego uzasadnienia i postulatu rzetelnej wymiany myśli. Zob. A. Brożek, M. Będkowski, A. Chybińska, S. Ivanyk, D. Traczykowski, Antyirracjonalizm. Metody filozoficzne w Szkole Lwowsko-Warszawskiej, Wydawnictwo Naukowe Semper, Warszawa 2020, s. 21.

6 Problematyka poglądów metodologicznych Tatarkiewicza podejmowana była m.in. przez: J.J. Jadackiego, Metodologia w ujęciu Władysława Tatarkiewicza, w: Władysław Tatarkiewicz: w siedemdziesięciolecie I wydania „Historii Filozofii”, red. Cz. Głombik, Gnome, Katowice 2003, s. 77-89; R. Kleszcza, W. Tatarkiewicz. Uwagi metafilozoficzne, „Zagadnienia Naukoznawstwa” 
metodologii ogólnej przy użyciu metody interpretacji twórczej ${ }^{7}$ Kazimierza Twardowskiego, wraz z uzupełnieniem tejże o rekonstrukcję jego poglądów z zakresu metodologii historii i historii filozofii po to, by nadać tym poglądom organiczny, tj. niefragmentaryczny charakter, którego dotąd nie otrzymały ${ }^{8}$. Ostatecznie będę argumentował za tezą o opisowym i eklektycznym charakterze poglądów historiograficznych Tatarkiewicza oraz o niektórych brakach jego metodologii historii i historii filozofii.

Dla każdej koncepcji metodologicznej istnieją dwa punkty wyjścia stanowiące jej założenia: ontologia i epistemologia, aby relewantnie bowiem odpowiedzieć na pytanie o to, „jak należy badać”, wpierw trzeba odpowiedzieć na pytanie o to, „co można badać” (co istnieje), oraz na idące w krok za nim pytanie, „w jaki sposób mogę badać to, co istnieje” (w jaki sposób przedmiot moich badań jawi się moim zmysłom). Dopiero po przyjęciu pewnej koncepcji nauki (resp. wiedzy) można zasadnie odpowiedzieć na pytanie, czy sposób, w jaki podmiot badający poznaje, ma charakter poznania naukowego, oraz w „jaki sposób wyniki tego poznania może przekazać innym” (czym jest i jaką rolę w procesie naukotwórczym odgrywa język). Powyższe ustalenia posłużą jako szkielet ramowy porządkujący podejmowane zagadnienie.

\section{Ontologia}

W przypadku założeń ontologicznych Tatarkiewicza jedynym możliwym postępowaniem jest rozumowanie redukcyjne ${ }^{9}$, biorące za podstawę jego poglądy

2017, 1(211), s. 29-48; R. Palacza, W. Tatarkiewicz jako historyk filozofii. Kilka uwag, „Filo-Sofija” 2011, nr 13-14 (2-3), s. 487-495; Z. Kuderowicza, Czy „Historia filozofii” należy do humanistyki rozumiejącej?, w: Władysław Tatarkiewicz: $w$ siedemdziesięciolecie..., dz. cyt., s. 41-54; tegoż, Przeglad metod historii filozofii, Zakład Narodowy im. Ossolińskich, Wrocław 1978; A.M. Nowika, Historiografia Władysława Tatarkiewicza $w$ kontekście sporów metodologicznych, „Filo-Sofija” 2011, nr 13-14 (2-3), s. 497-503.

7 Metodą interpretacji współtwórczej jest takie przeformułowanie wypowiedzi danej osoby, że: a) wypowiedź pozostaje zgodna $\mathrm{z}$ intencjami jej autora oraz b) wypowiedź staje się zrozumiała dla szerszego grona odbiorców.

8 Poglądy Tatarkiewicza na metodologię otrzymały swój najpełniejszy wyraz jak dotąd w książce Antyirracjonalizm..., dz. cyt.; publikacja ta nie zawiera jednak uwag do pisania tekstów naukowych, które Tatarkiewicz sformułował, a które zamieszczam w niniejszej publikacji.

9 Znana jest zawodność tego rozumowania, stąd też czytelnik musi mieć świadomość, że rekonstruowane tu założenia ontologiczne mają charakter jedynie prawdopodobny. Nadto, jak będę 
epistemologiczne, wyrażone w koncepcji „naturalnego obrazu świata” ${ }^{\text {. Autor }}$ Historii filozofii ujmuje tę rzecz następująco:
A. Świat przedstawia się każdemu jako zespół rzeczy materialnych, rozmiesz- czonych w przestrzeni i trwających w czasie. [...]
B. Drugą zaś jego cechą jest to, że rzeczy te posiadają różnorodne własności
[...]
C. Trzecią zaś cechą naszego obrazu świata jest to, że w nim świat występuje jako realny, od nas niezależny ${ }^{11}$.

Zdroworozsądkowość owego ujęcia pozwala wnosić, że to, co ujmują ludzkie zmysły, jest mniej lub bardziej adekwatne do stanu faktycznego ${ }^{12}$, stąd też konwersja na grunt ontologii owocuje następującym zbiorem tez: a) rzeczy materialne istnieją niezależnie od podmiotu poznającego, b) obdarzone są jakimiś własnościami (jakościami - qualia, które bezpośrednio poznajemy), c) mają charakter czasoprzestrzenny. Dla metodologii Tatarkiewicza jest to zbiór minimalny czerpiący swoje uzasadnienie $\mathrm{z}$ pierwotnego charakteru jego przedrefleksyjnej oczywistości ${ }^{13}$. Wykazanie jego błędności (a takie próby podejmował w przeszłości np. Berkeley) skutkowało fiaskiem, ponieważ nawet ci uczeni, którzy w swej pracy badawczej starali się mu zaprzeczyć, posługiwali się nim na co dzień.

\section{Epistemologia}

O ile świat zewnętrzny jest niezależny od podmiotu poznającego, o tyle wytworzony przezeń „naturalny obraz świata” zawiera w sobie czynniki subiektywne ${ }^{14}$,

wskazywał w dalszej części tekstu, stanowiące podstawę dla nauki naturalne ujęcie świata (i idąca w krok za nim naiwna ontologia) nie zawsze są zachowywane w nauce.

10 Pojęcie „naturalnego obrazu świata” nie jest równoważne pojęciu światopoglądu.

11 W. Tatarkiewicz, O filozofii i sztuce, Państwowe Wydawnictwo Naukowe, Warszawa 1986, s. 15.

12 „Do naszego obrazu świata mamy pełne zaufanie. Trudno nam dopuścić, by mógł być błędny lub subiektywny, by świat był naprawdę inny, niż go widzimy”. W. Tatarkiewicz, O filozofii i sztuce, dz. cyt., s. 18.

13 „Taki obraz świata jest dla człowieka «naturalny», w tym sensie, że narzuca się każdemu, że dojście do niego nie wymaga namysłu ani wysiłku. Jest obrazem «zdrowego rozsądku» - w tym sensie, że potrzebne są doń jedynie najpospolitsze czynności umysłu, a niepotrzebne wyszkolenie naukowe. Jest także obrazem "praktycznym» - w tym sensie, że w życiu praktycznym trzymamy się go bez zastrzeżeń", tamże, s. 18.

14 „Wydaje się nam, że wytworzyliśmy nasz obraz świata, licząc się tylko z jego naturą; tymczasem jest on uwarunkowany także naszą naturą. Uwarunkowany biologicznie i psychologicznie, 
ponieważ: 1) „Powstaje on głównie z wrażeń zmysłowych” ${ }^{15}$, a te są różne dla każdego, 2) „kształtuje [...] również dzięki wyobrażeniom”"16, w tym wyobrażeniom wytwórczym, 3) budujemy go zarówno z doświadczeń zewnętrznych, jak i wewnętrznych, a „cośmy doświadczyli na sobie, stosujemy do innych ludzi, a nawet do rzeczy”17, 4) „również i myśl nasza ma udział w postrzeganiu rzeczy”18, i to na dwóch płaszczyznach nadaje pewności naszym wrażeniom zmysłowym oraz pozwala bezpośrednie dane zmysłowe ujmować w sposób konceptualny ${ }^{19}$.

W powstaniu „naturalnego obrazu świata” biorą udział zarówno wrażenia zmysłowe, jak i podstawowe (świadome lub nie) rozumowania, stąd też zgodnie z tradycją filozoficzną Tatarkiewicz wyróżnia dwa rodzaje poznania ${ }^{20}$, nie poruszając przy tym zagadnienia intencjonalności poznania, przez co trudno rozstrzygnąć, czy stan świadomości, w którym umysł nie jest nakierowany na żaden przedmiot, autor Historii filozofii określiłby mianem poznania ${ }^{21}$.

Bez wątpienia takim mianem określiłby skupienie (koncentrację), które - idąc za przykładem Arystotelesa - dzieli na teoretyczne i praktyczne ${ }^{22}$ po to, by sku-

zależny jest od naszego tętna i budowy narządów zmysłowych, od właściwości naszego wyobrażenia i sądzenia. Jest też uwarunkowany społecznie, bo kształtujemy myśli nasze tak, by móc je przekazać innym. A także jest uwarunkowanym praktycznie, bo jest obrazem świata, którym posługujemy się w życiu i działaniu i który do użytku tego jest dostosowany; z różnorodnych sygnałów, jakie rzeczy dają nam o sobie, przy pomocy zmysłów podejmujemy te, które są dla nas praktycznie ważne, które umożliwiają nam i ułatwiają orientację w działaniu", tamże, s. 21.

15 Tamże, s. 18.

16 Tamże.

17 Tamże, s. 19.

18 Tamże, s. 20.

19 „Po wtóre w tym, że widzę dom - dom, a nie co innego - zawarte jest również myślenie. To właściwie widzę tylko przedmiot o pewnych kształtach i barwie i przedmiot ten zaliczam do domów. Włączam go do pewnej klasy, mianowicie klasy «domów», klasyfikuję, wydaję sąd”, tamże.

20 „Były i są rozróżniane dwa rodzaje poznania: umysłowe i zmysłowe. Zostały one z całą stanowczością przeciwstawione w starożytności jako aisthesis i noesis - dwa pojęcia stale wówczas używane i stale przeciwstawiane", W. Tatarkiewicz, Dzieje sześciu pojęć, Państwowe Wydawnictwo Naukowe, Warszawa 1982, s. 11.

21 „Przychodzą też bowiem chwile bez skupienia. Wtedy świadomość przebiega swobodnym a bystrym potokiem wrażeń, wyobrażeń, uczuć i pożądań, przerzucając się z tematu na temat, poddając się przypadkowym kojarzeniom i wraz nimi nieustannie zmieniając kierunek", W. Tatarkiewicz, O filozofii i sztuce, dz. cyt., s. 170

22 „Skupiamy się na przedmiocie, by coś z nim zrobić, przerobić go czy przekształcić, utrwalić czy usunąć; bądź też skupiamy się po to tylko, by go zobaczyć i poznać”, tamże, s. 167. Nie jest jasne, jak naturalny obraz świata ma się do skupienia i poznania biernego; najprawdopodobniej powstaje w wyniku obu, chociaż może powstawać w wyniku skupienia praktycznego (z uwagi na praktyczny charakter) oraz również w wyniku teoretycznego (z uwagi na to, że jego wytworem może być wiedza potoczna). 
pienie teoretyczne podzielić dalej na badawcze i kontemplacyjne, które następnie dzieli na estetyczne i literackie.

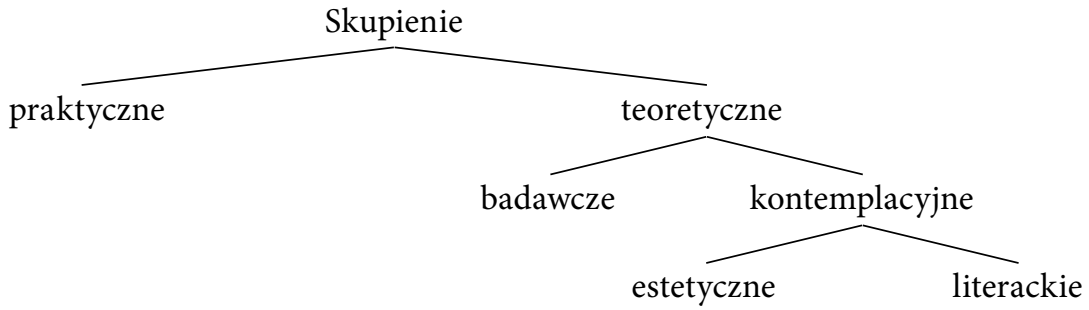

Rys. 1. Rodzaje skupienia według Władysława Tatarkiewicza.

W odniesieniu do skupienia badawczego Tatarkiewicz pisze:

Postawa badawcza i postawa estetyczna są obie apraktyczne, obie teoretyczne.

Są odmianami teoretycznego skupienia umysłu na rzeczach ${ }^{23}$.

W trakcie postawy badawczej podmiot tworzy wiedzę, gdy w skupieniu nakierowuje uwage na przedmiot badania, który poddaje kwalifikacji (ustala jego własności istotne), klasyfikacji (włącza do ogólniejszych zbiorów) oraz racjonalizacji (wskazuje związki z innymi przedmiotami, w tym przyczyny i cele) ${ }^{24}$.

Tatarkiewicz wyróżnia cztery typy wiedzy ${ }^{25}: 1$ ) wiedzę potoczną, 2) wiedzę naukową, 3) wiedzę zawodową ${ }^{26}$, 4) wiedzę spekulatywną. Powszechnie uznaje się, że to wiedza naukowa ma charakter wiedzy pewnej, niezawodnej, obiektywnej, ogólnej i intersubiektywnej (sprawdzalnej i komunikowalnej), jednak autor Historii filozofii wskazuje, że cechą istotową wiedzy naukowej jest jej uporządkowanie $^{27}$. Podstawą dla stworzenia wiedzy naukowej jest wiedza potoczna, która

\footnotetext{
Tamże, s. 168

J.J. Jadacki, Metodologia w ujęciu Władysława Tatarkiewicza, dz. cyt., s. 77.

W. Tatarkiewicz, O filozofii i sztuce, dz. cyt., s. 154.
}

26 Nie jest jasna relacja wiedzy zawodowej do rodzajów skupienia. Z jednej strony wszelka wiedza jest wytwarzana w skupieniu badawczym, z drugiej - Tatarkiewicz określa wiedzę zawodową jako sferę bardziej umiejętności niż przeświadczenia, co prowadzi do wniosku, że skupienie praktyczne (manualne), które owocuje doświadczeniem zrobienia czegoś, również wytwarzałoby wiedzę rozumianą jako umiejętność.

27 „Najpierw, nauka jest wiedzą wspólną: wspólną dla wszystkich, którzy robią odpowiedni wysiłek, aby ją zrozumieć. Następnie, jest wiedzą metodyczną, ułożoną wedle pewnego programu i zasad. Dalej, jest wiedzą sformalizowaną i symboliczną, wyrażoną w symbolach: w wyrazach 
stanowi epistemiczną warstwę naturalnego obrazu świata i jest zmienna, niezupełna, perspektywiczna, względna, nieuporządkowana i nieusystematyzowana. By uzyskać status wiedzy naukowej, musi zostać ulepszona, a to wymaga sześciu etapów:

A. Po pierwsze, na rozszerzaniu wiedzy potocznej. Nauka uwzględnia również to, co przekracza zwykłą obserwację [...]

B. Po drugie, ulepszanie wiedzy potocznej, dokonywane przez naukę, polega na sprawdzaniu i korygowaniu tego, co w niej jest błędne. [...]

C. Po trzecie, polega na dowodzeniu tego, co wiedza potoczna znała wprawdzie, ale jedynie jako domysł, i na wyjaśnianiu tego, co wiedza potoczna znała wprawdzie, ale jako niepojęty, niewyjaśniony fakt. [...]

D. Po czwarte: ulepszanie wiedzy potocznej przez naukę polega na jej uściślaniu, na mierzeniu i obliczaniu tego, co potocznie wie się tylko niedokładnie, ogólnikowo. Każdy wie, że jeśli rzuci kamień z góry, to będzie on spadać, ale trzeba było Galileusza, by znaleźć prawo tego spadania.

E. Po piąte, doskonalenie wiedzy przez naukę polega na jej porządkowaniu, na włączaniu luźnych obserwacji i częściowych uogólnień w większe systemy. [...]

F. Po szóste wreszcie: nauka zdaje się dążyć do ulepszenia wiedzy potocznej przez jej ograniczenie. Pomija własności rzeczy, które są subiektywne; czy nieuchwytne, które nie nadają się do ścisłego badania. Wyłącza ze swych rozważań wartości rzeczy, ich cel i to wszystko, co jest w nich rzeczą uczucia; nie mówi o sensie i przeznaczeniu życia, choć nie ma spraw, które by człowiekowi bardziej leżały na sercu. A wyłączając ze swego badania jedne własności, wysuwa przez to na pierwszy plan inne, właśnie te uchwytne, dające się ściśle badać, obiektywnie ujmować ${ }^{28}$.

Obszar wiedzy naukowej stanowi „naukowy obraz świata”. Można przy tym wyróżnić u Tatarkiewicza dwa rozumienia tego pojęcia: 1) ogólne, tj. całokształt wiedzy wszystkich nauk, oraz 2) szczegółowe, tj. całokształt wiedzy danej nauki, np. chemii, fizyki, biologii lub pewnego zbioru nauk, np. nauk empirycznych, typologicznych itp.

języka, cyfrach, formułach, tabelach. Jednakże wszystkie te właściwości nauki mieszczą się w tym szeroko rozumianym określeniu: że jest wiedzą uporządkowaną", tamże, s. 155.

Tamże, s. 24-25. 
Tatarkiewicz zwraca uwagę, że obraz świata większości nauk nomologicznych i typologicznych w swej głównej osnowie pozostaje zbieżny $\mathrm{z}$ obrazem naturalnym, a różnica między nimi jest natury jakościowej ${ }^{29}$ - obraz naukowy jest bardziej uogólniony, ujednostajniony, usystematyzowany i uproszczony. Inaczej rzecz ma się z obrazem fizykalnym. Obraz ten, chociaż początkowo nawiązywał do naturalnego obrazu świata, wraz z rozwojem i usamodzielnianiem się nauk zerwał z nim, proponując odrębne ujęcie rzeczywistości ${ }^{30}$. Obraz świata proponowany przez fizykę jest obrazem ilościowym (pozbawia rzeczy cech jakościowych, pozostawiając tylko wielkości), wyjaśnianym kauzalnie (a nie teleologicznie), dynamicznym (ujmuje świat jako zespół procesów, a nie rzeczy).

Przy okazji rozróżnienia dotyczącego świata naukowego i naturalnego, pojawia się pytanie o to, który z nich lepiej oddaje rzeczywistość. W tej kwestii Tatarkiewicz odpowiada następująco:

Jednym słowem: wypadki rozbieżności między naturalnym a naukowym obrazem świata można rozstrzygać na korzyść nauki, ale można również rozstrzygać na korzyść naturalnego obrazu. Trafność naukowego obrazu świata może wzbudzać wątpliwości tak samo jak trafność obrazu naturalnego. [...] Bo jeśli obraz naturalny deformują potrzeby praktyczne życia, to znów obraz fizykalny deformuje potrzeba ścisłego obliczania i mierzenia ${ }^{31}$.

\section{Nauka}

Tatarkiewicz wyróżnia cztery sposoby rozumienia słowa „nauka”, biorąc za podstawę dwa dychotomiczne odróżnienia: a) odróżnienie czynności i wytworów ${ }^{32}$ (nauka jako czynność badania i jako wynik badań np. książki), b) wąski i szeroki

\footnotetext{
29 „Nauka nawiązuje do wiedzy potocznej, usiłuje ją w szczegółach ulepszyć i rozwinąć systematycznie, z możliwą zupełnością, ścisłością, ostrożnością, odpowiedzialnością, bezstronnością", tamże, s. 24.

30 „Wszak fizyka mogłaby zachować naturalny obraz świata, a jeśli nie zachowuje, to dlatego, że chce zastąpić go przez doskonalszy, chce usunąć braki tamtego, jego względność i subiektywność", tamże, s. 35.

31 Tamże, s. 37.

32 Tatarkiewicz korzysta z rozróżnienia Kazimierza Twardowskiego na czynności i wytwory.
} 
sens (nauka jako dyscyplina posiadająca wydzielony, ograniczony zakres badania i jako każde metodyczne, technicznie udoskonalone zdobywanie wiedzy) $)^{33}$.

Tatarkiewicz porusza również zagadnienie rozwoju nauki, zauważając, że rozwój odbywa się w sposób nieprzewidywalny, a główną jego siłą napędową nie są geniusze, których było stosunkowo niewielu, lecz umiarkowanie inteligentni, sumiennie pracujący naukowcy, którzy potrafią spojrzeć na problem z nowej perspektywy. Większość wielkich odkrywców była właśnie takimi „szczęściarzami”, którzy dzięki odpowiedniemu zapleczu społecznemu i historycznemu, szczęśliwemu ukształtowaniu umysłu oraz zwykłemu przypadkowi dokonali przełomowego odkrycia.

\section{Klasyfikacja nauk}

Autor Historii filozofii podejmuje również zagadnienie klasyfikacji nauk, mając za podstawę historyczne podziały ${ }^{34}$, które były dokonywane z uwagi na: 1) przedmiot badania (np. przyrodnicze - humanistyczne), 2) własności badanych przedmiotów (np. fizyka - chemia), 3) metody badawcze (np. indukcyjne - dedukcyjne), 4) status proponowanych twierdzeń (np. ogólne - szczegółowe), 5) cel (np. stosowane - czyste), 6) przyjętą definicję nauki lub wiedzy (np. dyscypliny techniczne - filozofia), 7) względy praktyczne ${ }^{35}$ (np. sermocinales - reales i odpowiednik trivium - quadrivium), 8) zadania, jakie wypełniają (np. nomologiczne - typologiczne). Podkreśla, że:

Najważniejsze zaś jest to, że pod nazwą „klasyfikacji nauk” występują dwie sprawy zupełnie różne: po pierwsze, podzielenie nauk na grupy nauk do sie-

33 Analogicznie do ogólnego i szczegółowego rozumienia „naukowego obrazu świata”: „Nauką nazywamy poszczególne dyscypliny: nauką jest dla nas algebra czy chemia; ale kiedy indziej przez naukę rozumiemy całokształt wiedzy, zespół wszystkich dyscyplin”, tamże, s. 154.

34 Tatarkiewicz nie kwestionuje zasadności wszystkich przywołanych podziałów. Dla przykładu w jego pismach funkcjonuje również podział na nauki humanistyczne i przyrodnicze oraz nauki czyste i stosowane. Podziały te mają charakter drugorzędny, dlatego jako główny podział wskazuję klasyfikację na nauki nomologiczne i typologiczne, która krzyżuje się z powyższymi.

35 Podstawą podziału może być kryterium praktycznej organizacji nauki, np. wydzielanie fakultetów, organizacja toku nauczania, finansowanie poszczególnych dyscyplin. 
bie podobnych, a po wtóre, uszeregowanie ich, zestawienie według określonej zasady, wprowadzenie do nich racjonalnego układu ${ }^{36}$.

Proponuje przy tym zmodyfikowany podział nauk, dzieląc je (za Twardowskim ${ }^{37}$ najpierw $z$ uwagi na sposób uzasadniania twierdzeń na nauki aprioryczne - badające związki między twierdzeniami - oraz nauki empiryczne - badające fakty. Następnie dokonuje podziału z uwagi na zadania nauk na nomologiczne ${ }^{38}$ i typologiczne oraz szereguje nauki typologiczne według sposobu, w jaki wydzielają typy. Podział ten przedstawia się następująco ${ }^{39}$ :

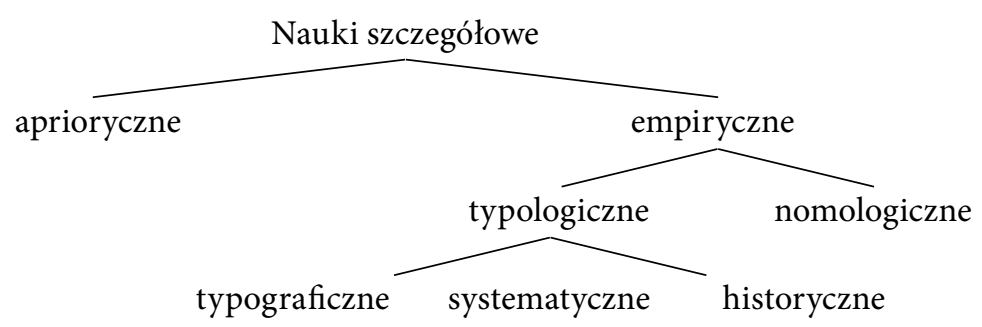

Rys. 2. Podział nauk szczególowych według Władysława Tatarkiewicza.

Podczas analizy powyższej klasyfikacji nauk, nasuwa się pytanie, do której grupy nauk zalicza się filozofia, ani bowiem nie odkrywa ona praw, ani nie wyróżnia typó ${ }^{40}$. W istocie Tatarkiewicz przyznaje, że jeśli przyjmie się wąskie ro-

36 W. Tatarkiewicz, Droga do filozofii i inne rozprawy filozoficzne, w: tegoż, Pisma zebrane, t. I, Państwowe Wydawnictwo Naukowe, Warszawa 1971, s. 54.

37 „Nie sposób wykrywania, wynajdywania prawd, nie droga, po której nauki do nowych twierdzeń dochodzą, lecz sposób ich uzasadniania jest podstawą podziału nauk na aprioryczne, czyli racjonalne, i aposterioryczne, czyli empiryczne". K. Twardowski, Wybrane pisma filozoficzne, Państwowe Wydawnictwo Naukowe, Warszawa 1965, s. 367-368.

38 Tatarkiewicz używa słowa nomologiczne zamiast nomotetyczne, by nie przesądzać, czy prawa naukowe są odkrywane czy też ustanawiane.

39 Należy nadmienić, że kwestia klasyfikacji nauk u Tatarkiewicza wyłożona jest w sposób dosyć zawiły. Przedstawiam tu jej taką rekonstrukcję, którą w mojej ocenie można mu przypisać z dosyć dużym prawdopodobieństwem. Jednocześnie w literaturze proponuje się także inne ujęcia tego zagadnienia. Por. J.J. Jadacki, Metodologia w ujęciu Władysława Tatarkiewicza, dz. cyt., oraz R. Kleszcz, W. Tatarkiewicz. Uwagi metafilozoficzne, dz. cyt., s. 29-48.

40 „Rozwiązanie może leżeć w tym, że filozofia stanowi trzecią jeszcze grupę nauk, ustalającą nie prawa i nie fakty, lecz jakieś ogólne hipotezy co do natury rzeczy czy poznania. Ale może też być inne: filozofia nie mieści się w żadnej z grup nauk, bo - nie jest w ogóle nauką. Jest czymś mniej, lub czymś więcej niż nauką", W. Tatarkiewicz, Droga do filozofii..., dz. cyt., s. 61. 
zumienie nauki, to okazuje się, że filozofia nią nie jest, może nią być tylko w szerokim sensie tego słowa, a wtedy przedmiotem jej badań będą założenia wspólne wszystkim naukom, granice oraz prawa myśli, według których się je tworzy. Będzie zatem nauką wyższego rzędu, łączniczką pomiędzy poszczególnymi naukami oraz łączniczką pomiędzy potocznym a naukowym obrazem świata, dyscypliny przynależne zaś filozofii oraz dokładny zakres jej badań wyznacza minimalistyczny ${ }^{41}$ lub maksymalistyczny ${ }^{42}$ stosunek do zagadnień granic ludzkiego poznania $^{43}$.

\section{Podstawowe pojęcia nauki}

Biorąc za podstawę klasyfikację nauk, Tatarkiewicz wyróżnia cztery podstawowe pojęcia nauki:

Każdy dział nauk posiada swe odrębne pojęcia. Dla nauk apriorycznych fundamentalne jest pojęcie pewnika, a dla empirycznych - faktu: specjalnie zaś dla nauk nomologicznych ważne jest pojęcie prawa naukowego, a dla typologicznych - pojęcie typu. Cztery te pojęcia wydają się proste, ale nie są proste i wymagają wyjaśnienia ${ }^{44}$.

Oto zrekonstruowane definicje powyższych pojęć:

- Pewnik (aksjomat) to twierdzenie przyjęte bez dowodu po to, by ustalić, co z niego wynika. O wyborze pewników decydują wygoda, ekonomia i płodność wyników.

41 „Filozofia moja jest porządkowaniem pojęć, nic więcej. Mianowicie tych, którymi się stale posługuję i które są na tyle pociągające, że można o nich książki nie tylko pisać, ale nawet wydawać. [...] Chcę tylko przejrzyście ułożyć pojęcia, jakimi się posługuję, - to nie jest znów tak mało”, cyt. za: R. Kleszcz, W. Tatarkiewicz..., dz. cyt., s. 37.

42 „Rozumiem potrzebę systemu filozoficznego, ale mnie ten trud nie pociąga. Czasem myślę, że nie jest to zadanie na miarę człowieka, w każdym razie nie jest na moją. Jeślibym miał przyznać się do jakiegoś systemu, to do arystotelesowskiego", cyt. za: R. Kleszcz, W. Tatarkiewicz..., dz. cyt., s. 33 .

43 „Filozofia może być pojmowana - jak u Cournota - nie jako oddzielna nauka czy grupy nauk, lecz jako składnik wszystkich nauk. Albo - jak u współczesnych pozytywistów - jako zabieg przygotowawczy do nauk, jako sztuka, wytwarzająca dla nauk odpowiednie pojęcia podstawowe i dyrektywy metodologiczne. Albo też filozofia, gdy jest pojmowana jako metafizyka, może być zbliżana raczej do religii niż do nauki”, W. Tatarkiewicz, Droga do filozofii..., dz. cyt., s. 61-62.

W. Tatarkiewicz, O filozofii i sztuce, dz. cyt., s. 32. 
- Fakt naukowy to fakt ustalony na podstawie faktów bezpośrednio obserwowanych ${ }^{45}$, przy zastosowaniu rozumowania bazującego na znanych podmiotowi prawach naukowych.

- „Prawo naukowe jest ustaleniem stałego związku między zjawiskami stałego następstwa lub wspólistnienia. Wypowiadane jest w twierdzeniach ogólnych mających postać «każde $A$ jest $B »$ lub «ilekroć $A$, to i $B{ }^{{ }^{*}}{ }^{46}$.

- Typ to zespół takich własności, że: a) powtarza się wśród egzemplarzy jakiejś klasy zjawisk; b) w innych egzemplarzach tej samej klasy jest zastąpiony przez innych zespół.

Przywołany zestaw uwidacznia przekonanie Tatarkiewicza o komplementarności pojęcia typu względem pojęcia prawa naukowego. Wyróżnianie typów i ustalanie lub odkrywanie praw pod względem istotności są równorzędnymi operacjami naukotwórczymi, nawet jeśli niekiedy ustalenie typu może stanowić czynność przygotowawczą względem ustalenia lub odkrycia praw, można bowiem wyróżniać prawa naukowe pomiędzy typami.

Myśl potoczna także wyróżnia typy, ustala fakty i formułuje prawa, jednak nauka dokonuje tych czynności w sposób doskonalszy. Wyróżnianie typów w myśli potocznej odbywa się intuicyjnie - w nauce natomiast świadomie, myśl potoczna ogranicza się do ustalenia faktów - naukę interesuje również sposób ich ustalenia, myśl potoczna formułuje tylko prawa ogólnikowe ${ }^{47}$ - dla nauki prawa takie mogą stanowić punkt wyjścia, lecz dąży ona zawsze do praw analitycznych ${ }^{48}$. W życiu codziennym można zaobserwować tylko przypadki praw ogólnikowych, prawa analityczne bowiem zawierają w sobie czynnik idealizacyjny. Opisują zależności nie pomiędzy złożonymi zjawiskami, lecz pomiędzy własnościami tych zjawisk z pominięciem zjawisk współwystępujących, np. prawo powszechnego ciążenia pomija występowanie oporu powietrza, jaki działa na spadające ciało.

45 Fakty naukowe nie są tym, co bezpośrednio stwierdzamy w poznaniu naukowym. Bezpośrednio dostrzegamy tylko ruch wskazówki na skali (fakt bezpośrednio stwierdzony), na podstawie znajomości praw naukowych rozumuję, że zwiększył się opór elektryczny przewodu (fakt naukowy). Wynika stąd po pierwsze, że fakty naukowe mogą być ustalone błędnie, a po drugie, że pomiędzy faktami a prawami nauki zachodzi wzajemna relacja (ustalanie faktów zakłada znajomość praw, a ustalanie praw zakłada znajomość faktów), nie jest zatem prawdą, że nauka rozwija się w prosty sposób od faktów do praw. W. Tatarkiewicz, O filozofii i sztuce, dz. cyt., s. 33.

47 Przykład ogólnikowego prawa myśli potocznej: „Woda zamarza, gdy jest zimno”.

48 Przykład analitycznego prawa nauki: „Zamarzanie czystej wody, przy ciśnieniu atmosferycznym wynoszącym $101325 \mathrm{~Pa}$, zachodzi w temperaturze $0^{\circ} \mathrm{C}$ ". 


\section{Czynności naukotwórcze}

Prawie każda nauka dąży zarówno do ustalenia twierdzeń najogólniejszych, jak i formułowania twierdzeń szczegółowych, czynności naukowe zaś podążają w trzech głównych kierunkach: 1) opisu, 2) wyjaśniania, 3) przewidywania ${ }^{49}$.

Ad 1) Opisem w szerokim sensie są: a) stwierdzanie zjawisk, b) opis zjawisk $\mathrm{w}$ twierdzeniach jednostkowych, c) uogólnienie twierdzeń jednostkowych, d) uzasadnienie twierdzeń, e) porządkowanie zjawisk ${ }^{50}$ (szeregowanie, klasyfikacja i typologizacja). Opisem w wąskim sensie są tylko a i b, natomiast c, d i e $\mathrm{e}^{51}$ stanowią odrębne i przeciwstawne czynności naukowe, przy czym:

Uogólnienie (generalizacja) to rozwinięcie twierdzenia jednostkowego do postaci ogólnej, przy użyciu wnioskowania, które jest zawodne - może prowadzić do generalizacji idącej zbyt daleko (przesadnej).

Uzasadnianie to podanie argumentu (racji) dla pewnego twierdzenia w postaci dowodu lub potwierdzenia (za pomocą intuicji, oczywistości, bezpośredniej świadomości) prawdziwości tego twierdzenia. Argumentacja może być błędna za sprawą niedokładnej obserwacji lub użycia wadliwego sylogizmu.

Ad 2) Wyjaśnienie to zrozumienie zjawiska poprzez wskazanie jego genezy lub kontynuacji, czyli umieszczenie zjawiska w pewnym szeregu rozwojowym. Wyjaśnienie opiera się na hipotezach i można go dokonać poprzez: 1) wskazanie warunków wystarczających, niezbędnych lub sprzyjających dla zaistnienia zjawiska, 2) wskazanie czynników przeciwdziałających powstaniu zjawiska, 3) wskazanie proporcjonalności lub „augmentatywności” zjawiska ${ }^{52}$. Wyjaśnienie może zawierać wszystkie z powyższych lub tylko niektóre.

Ad 3) Przewidywanie (prognozowanie) to ustalanie, co nastąpi w danych okolicznościach. Prognozowanie może się nie powieść z uwagi na: 1) dysproporcję pomiędzy zależnymi zjawiskami, 2) brak stałej zależności między zjawiskami znanymi a szukanymi, 3) chronologiczną i pozycyjną deformację przewidywanych zjawisk.

\footnotetext{
49 Por. J.J. Jadacki, Metodologia w ujęciu Władysława Tatarkiewicza, dz. cyt., s. 88-89.

50 „Klasyfikacja jest szeroko pojętym opisem”, W. Tatarkiewicz, O filozofii i sztuce, dz. cyt., s. 143.

51 Czynności porządkujące, szczególnie klasyfikacja i typologizacja, zostaną omówione szerzej w innej części tekstu.

52 J.J. Jadacki, Metodologia w ujęciu Władysława Tatarkiewicza, dz. cyt., s. 88-89.
} 


\section{Definiowanie ${ }^{53}$}

Zarówno typologia, jak i klasyfikacja są operacjami, których dokonujemy na przedmiotach, lecz jak zauważa Tatarkiewicz:

Są też z naciskiem rozróżniane: świat i język, którym o świecie mówimy; inaczej: rzeczy i znaki. Nieco inaczej: rzeczy i symbole. Rozróżnienie to nie zawsze było na pierwszym planie nauki, w szczególności o pięknie i sztuce, ale sięga czasów wczesnej kultury greckiej, w której już przeciwstawiano rzecz i nazwę: rema i onoma ${ }^{54}$.

Stąd też wyniki tych czynności wyrażamy w języku, który dla Tatarkiewicza jest sztucznym i umownym zbiorem znaków dostępnych dla wzroku lub słuchu ${ }^{55}$. Jest sztuczny, bo jest wytworem człowieka, a nie natury, jest umowny, ponieważ „możemy tylko umówić się, że ilekroć będziemy mieć na myśli przedmiot pewnego rodzaju, to dla porozumienia się będziemy używać pewnego znaku"56. Obie te cechy pozwalają wyrażać i utrwalać w nim myśli, a zatem przekazywać wiedzę innym, czyniąc ją wspólną. Szczególnym rodzajem znaków języka są nazwy, które nadajemy przedmiotom. Większość nazw powstała w sposób spontaniczny, a zatem są wieloznaczne, zmiennoznaczne, abstrakcyjne, niepojęte, nieostre, mętne, płynne, nietrwałe i niezrozumiałe ${ }^{57}$. Posługujemy się nimi na co dzień w mowie potocznej, jednak:

Naczelnym wymaganiem stawianym przez naukę językowi jest, aby każdy jego wyraz miał jedno tylko znaczenie. Inaczej mówiąc: aby było jedno tylko pojęcie tam, gdzie jest jeden wyraz. Wymaganiu temu nie czyni jednak zadość większość wyrazów mowy potocznej, do której wyraz „szczęście” należy ${ }^{58}$.

Umowność języka natomiast pozwala posługiwać się nim precyzyjnie między innymi dzięki definiowaniu nazw potocznych. Tatarkiewicz podaje następujące rozumienie definicji:

\footnotetext{
53 Szersze ujęcie tego zagadnienia proponuje J.J. Jadacki, Metodologia w ujęciu Władysława Tatarkiewicza, dz. cyt., s. 83-85.

54 W. Tatarkiewicz, Dzieje sześciu pojęć, Państwowe Wydawnictwo Naukowe, Warszawa 1982, s. 11-12.

55 Tatarkiewicz pomija kwestię reguł języka.

56 W. Tatarkiewicz, O filozofii i sztuce, dz. cyt., s. 22.

57 J.J. Jadacki, Metodologia w ujęciu Władysława Tatarkiewicza, dz. cyt., s. 83.

58 W. Tatarkiewicz, O szczęściu, Państwowe Wydawnictwo Naukowe, Warszawa 2003, s. 15.
} 
Definicją nazywa się zdanie podające znaczenie jakiejś nazwy. Inaczej: definicja nazwy jest to zdanie podające pojęcie odpowiadające tej nazwie. Jeszcze inaczej: jest to wymienianie klasy przedmiotów oznaczanej przez tę nazwę. Najkrócej: to wyjaśnienie nazwy. Definicja ma zawsze postać zdania: podmiotem jest w nim nazwa, a orzecznikiem - odpowiadające jej pojęcie. Np. definicja: „«Kapitel» jest to wieńcząca część kolumny” jest równoważna ze zdaniem: „Nazwa «kapitel» oznacza wieńczącą część kolumny”59.

W takim rozumieniu definicja jest twierdzeniem ogólnym, które przypisuje przedmiotom taki zbiór własności, że na jego podstawie można odróżnić przedmioty tej klasy od innych przedmiotów.

Tatarkiewicz wyróżnia trzy rodzaje definicji ${ }^{60}$ : projektującą (syntetyczną) i sprawozdawczą (analityczną) oraz regulującą ${ }^{61}$. Definicja projektująca wprowadza nową nazwę i nowe pojęcie, inaczej mówiąc, badacz na drodze dekretu postanawia, że dowolnie wybrana nazwa otrzyma takie a nie inne znaczenie. Definicja sprawozdawcza zdaje relację ze sposobu, w jaki dana nazwa jest rozumiana, inaczej mówiąc, badacz zdaje relację z uzusowego znaczenia danej nazwy, najpierw ustaliwszy je na drodze indukcji ${ }^{62}$. Definicja regulująca „zachowuje to, co treść pojęcia przesądza w sposób niewątpliwy, a wątpliwości graniczne przecina konwencją"63.

Definicje analityczne urabiamy za pomocą indukcji zupełnej lub niezupełnej ${ }^{64}$, przy czym Tatarkiewicz indukcję zupełną nazywa „metodą indukcyjną”, indukcję niezupełną zaś „metodą intuicyjną"65.

59 W. Tatarkiewicz, Dzieje sześciu pojęć, dz. cyt., s. 16-17.

60 Tamże, s. 17 oraz 399.

${ }_{61}$ J.J. Jadacki, Metodologia w ujęciu Władysława Tatarkiewicza, dz. cyt., s. 84.

62 Takie rozumienie definicji analitycznej i syntetycznej jest zgodne z pierwszą wersją (z czterech funkcjonujących w nauce) rozumienia podziału na definicje analityczne i syntetyczne zaproponowanego przez Janinę Kotarbińską w tekście Definicja, w: tejże, Z zagadnień teorii nauki i teorii języka, Państwowe Wydawnictwo Naukowe, Warszawa 1990, s. 136-138.

63 J.J. Jadacki, Metodologia w ujęciu Władysława Tatarkiewicza, dz. cyt., s. 84.

64 Indukcję Kotarbińska określa mianem zarówno metody dochodzenia do definicji, jak i metody „uzasadnienia twierdzenia, że dana definicja spełnia warunki, które się jej postawiło”. Metoda indukcyjna jest inaczej metodą heurystyczną. J. Kotarbińska, Definicja, dz. cyt., s. 144.

65 „Nawet pojęć tak prostych jak kapitel nikt nie definiuje i nie może definiować na drodze (zupełnej) indukcji; tym bardziej tak złożonych, płynnych, abstrakcyjnych, jak piękno czy forma. Postępuje się inaczej, robi się przegląd przykładów, starając się dobierać jak najbardziej różnorodne. Jest to metoda intuicyjna, bo wedle intuicji dobiera przykłady. Nie jest oczywiście niezawodna, ale trudno o lepszą", W. Tatarkiewicz, Dzieje sześciu pojęć, dz. cyt., s. 17. 
Metoda indukcyjna polega na porównywaniu między sobą egzemplarzy (identycznych bądź przynajmniej podobnych pod pewnymi względami ${ }^{66}$ ) po to, by ustalić rodzaj, do którego należą, oraz wyodrębnić zespół ich cech istotnych.

Metoda intuicyjna polega na wybraniu jednego lub kilku desygnatów nazwy, co do których badacz jest przekonany, że są one reprezentatywne, typowe lub wzorowe dla klasy ${ }^{67}$. Przy wyborze badacz kieruje się intuicją, stąd też czynność ta ma charakter subiektywny, dopiero powstała na jej podstawie definicja ma charakter obiektywny.

$\mathrm{W}$ definiowaniu podajemy znacznie jakiejś nazwy, lecz:

Nazwy mają dwojaką funkcję: coś znaczą i coś oznaczają. [...] Do znaczenia nazwy sprowadza się to, co nazywamy pojęciem. Mieć pojęcie kapitelu, dzieła sztuki czy piękna, to nic innego jak używać nazw: „kapitel”, „dzieło sztuki”, „piękno”, znając ich znaczenie. A także tyle, co wyodrębniać wśród przedmiotów klasę kapiteli, dzieł sztuki, piękna. Pojęcie, nazwa, klasa - to tylko różne aspekty tego samego zabiegu: wydzielania ze świata przedmiotów do siebie podobnych, łączenia ich $\mathrm{w}$ grupy $^{68}$.

Porządkujemy, grupujemy zjawiska i nadajemy im nazwy po to, by co do zasady różnoraka i chaotyczna w swych przejawach rzeczywistość stała się dla nas intelligibilna. Dzięki tworzeniu nazw i pojęć operujemy heterogenicznymi grupami zjawisk, tak jakby były jednolite, ponieważ „rzeczy wydają się stałe, gdy posiadają stałe nazwy i wydają się podobne, gdy posiadają nazwy podobne"69. Głównymi czynnościami porządkującymi są klasyfikacja i typologia.

\section{Klasyfikacja}

Tatarkiewicz wyszczególnia: 1) szerokie i 2) wąskie rozumienie klasyfikacji. Klasyfikacją w szerokim znaczeniu będzie każde porządkowanie zjawisk, a zatem:

66 „Poszczególne fakty, artystyczne czy filozoficzne, są może niepowtarzalne. Ale powtarzają się fakty do nich podobne, powracają egzemplarze tego samego typu", tenże, O filozofii isztuce, dz. cyt., s. 144.

67 Takie rozumienie metody intuicyjnej zakłada, że w fazie przygotowawczej dla właściwej definicji posługujemy się definicją deiktyczną, jak zwraca uwagę Janina Kotarbińska: „W przypadku gdy przedmioty wzorcowe są nam dane $\mathrm{w}$ doświadczeniu spostrzeżeniowym, mamy tu do czynienia $\mathrm{z}$ definicją deiktyczną", J. Kotarbińska, Tak zwana definicja deiktyczna, w: tejże, Z zagadnień teorii nauki i teorii języka, dz. cyt., s. 276.

68 W. Tatarkiewicz, Dzieje sześciu pojęć, dz. cyt., s. 16.

69 Tenże, O filozofii i sztuce, dz. cyt., s. 22. 
a) szeregowanie (porządkowanie zjawisk wedle jakiejś reguły, np. skali, chronologii, artyzmu), b) typologizacja (wyróżnianie w szeregu miejsc zagęszczonych) oraz c) klasyfikacja sensu stricto (podział logiczny).

W wąskim znaczeniu klasyfikacja to podział logiczny zjawisk według formalnej zasady albo-albo, w efekcie którego powstają mniejsze zbiory (klasy, gatunki). W klasyfikacji grupuje się zjawiska, które mają z sobą coś wspólnego i dają się objąć jednym pojęciem, przez co w wyróżnionej klasie wszystkie zjawiska mają z sobą coś wspólnego ex definitione. Co do zasady klasyfikacja jest czynnością bezhipotetyczną, dzięki czemu jej wyniki są pewne i dokładne, staje się operacją hipotetyczną tylko, gdy dzieli zjawiska z uwagi na ich pochodzenie, wtedy przejmuje hipotetyczność dociekań genetycznych.

Podstawę klasyfikacji stanowią łatwo rozpoznawalne ${ }^{70}$ własności istotne zjawisk $^{71}$, które określane są abstrakcyjnie, pojęciowo. Dokonanie podziału według cech drugorzędnych lub trudno rozpoznawalnych godzi w użyteczność klasyfikacji i obniża jej wartość poznawczą. Prawidłowa klasyfikacja musi być także: 1) wyczerpująca (gdy każde z dzielonych zjawisk przynależy do jakiejś klasy), 2) rozłączna (gdy nie ma takich zjawisk, które przynależą do więcej niż jednej klasy), 3) stanowcza (gdy o każdym zjawisku można orzec, czy przynależy do danej klasy).

\section{Typologizacja}

Pojęcie typu jest podrzędne względem gatunku, klasy i bywa używane chwiejnie. Niekiedy przez typ rozumie $\operatorname{się}^{72}$ : a) zespół cech (x realizuje typ), b) zespół egzemplarzy (x należy do typu), c) prototyp (x przypomina typ), d) egzemplarz (x jest typem). Nadto, można pojęcia typu używać w wąskim i w szerokim sensie. Typem w szerokim sensie jest pewna postawa psychologiczna przejawiana w wy-

70 „Ażeby klasa była użyteczna, ważne jest, by własności, na podstawie których została uformowana, dawały się rozpoznać i aby zawsze można było orzec, czy jakiś przedmiot do niej należy". W. Tatarkiewicz, Dzieje sześciu pojęć, dz. cyt., s. 12

${ }^{71}$ „Klasa przedmiotów zielonych (by wziąć przykład spoza estetyki), obejmująca trawę, szmaragdy, niektóre papugi, malachit i wiele innych rzeczy, mało jest użyteczna, bo przedmioty zielone niewiele poza tym mają wspólnego, niewiele można łącznie o ich klasie powiedzieć”. Tamże, s. 12.

72 „Trzeba wybrać między tymi znaczeniami «typu». Mowa potoczna najchętniej używa wyrazu w znaczeniu egzemplarza, ale w języku naukowym utarło się rozumieć przezeń abstractum, zespół cech". Tamże, s. 117. 
tworach nawet bardzo od siebie różnych, np. barokowe krzesło i żyrandol, mętny tekst filozoficzny i reklamowy. Typ w wąskim sensie jest wyznaczony na podstawie obserwowalnych własności rzeczy, a nie na podstawie postawy psychicznej, jaka je wydała.

W typie rozumianym jako zbiór egzemplarzy można wyróżnić: prototyp - egzemplarz chronologicznie najwcześniejszy; egzemplarz reprezentatywny (wzór) - egzemplarz ukazujący najwyraźniej pewien zespół cech ${ }^{73}$; egzemplarz przeciętny - egzemplarz pomiędzy skrajnymi krańcami typu; egzemplarze skrajne - egzemplarze wyznaczające granice typu, co do których istnieje uzasadniona wątpliwość, czy przynależą, czy też nie przynależą to typu.

Tatarkiewicz wyszczególnia następujące rodzaje typów: a) historyczne (powstałe w pewnym czasie lub środowisku) i systematyczne (ponadczasowe), b) stałe (niezmienne) i ewoluujące (zmienne), c) gradacyjne (ciągłe) i dyskretne (nieciągłe), d) wariantowe (posiadające różne odmiany) i inwariantne (nieposiadające odmian $)^{74}$.

Typy wyróżnia się dwuetapowo, wpierw stosując metodę empiryczną, następnie metodę idealizacyjną. Część empiryczna polega na wyodrębnieniu w pewnej klasie zjawisk szeregu zjawisk podobnych ${ }^{75}$ pod pewnymi względami, to jest takich, że można wyróżnić zespół cech im wspólnych ${ }^{76}$, przy czym nie wszystkie egzemplarze muszą posiadać wszystkie wyróżnione cechy ${ }^{77}$ lub posiadać je $\mathrm{w}$ równym stopniu ${ }^{78}$. Stąd też ustalenie grupy egzemplarzy typowych ma charakter intuicyjny, a przynależność niektórych z nich może być umowna, bowiem

73 Posiadający najwięcej cech typowych i posiadający je w jak największym stopniu.

74 Por. J.J. Jadacki, Metodologia w ujęciu Władysława Tatarkiewicza, dz. cyt., s. 87-88.

75 „W praktyce typ bywa często ustalony na podstawie pewnych wydatnych, a nawet jednego szczególniej uderzającego egzemplarza. Bierze się go za wzór i na jego podstawie ustala się zasięg typu: włącza się mianowicie do typu te zjawiska, te człony szeregu, które są owemu wzorowi bliskie". W. Tatarkiewicz, Skupienie i marzenie, dz. cyt., s. 114.

76 Przy czym należy wyszczególnić zespół własności istotnych, które będą stanowić cechy definicyjne typu.

77 „Prawie zawsze możemy spotkać dzieła, których przynależność do typu jest sporna. A także takie, które nie należą do żadnego typu. Tak że ostatecznie określeniom typu należy dawać nie formułę: «Budowla posiadająca cechy a, b, c..», lecz: «Budowla posiadająca większość cech a, b, c..»". W. Tatarkiewicz, O filozofii i sztuce, dz. cyt., s. 125.

78 „Ale dachy «niepłaskie» stanowią grupę bardzo niejednolitą, właściwie całą skalę dachów, która zaczyna się od dachu płaskiego i w sposób ciągły odeń się oddala. Własności tego rodzaju nazywać możemy «ciągłymi», w przeciwieństwie do «nieciągłych». Wraz z nimi wchodzi do określenia typów czynnik niedokładności, gdyż mogą być wyznaczone tylko w sposób przybliżony". Tamże, s. 122. 
tylko przedmioty tworzone seryjnie przez człowieka w ramach jednego typu są identyczne. Jak pisze Tatarkiewicz:

Zasadniczo typy ustala się empirycznie: obserwuje się zjawiska i na tej podstawie się je grupuje; ale są trudności, graniczne wypadki są prawie zawsze wątpliwe i przeto oddzielenie typu nie jest ostre. Jeśli się chce uniknąć nieostrości, to trzeba zrezygnować z dokładnej stosowalności pojęcia typu, trzeba utworzyć typ idealny. Idealny znaczy tu tyle, co „ściśle pojęciowy, określony bez odwoływania się do rzeczywistości”. Dlatego przy wszelkich typach trzeba wybierać między nieostrością a nierealnością.

I dlatego przy określaniu typów przechodzi się - w sposób mniej lub więcej świadomy - od empirycznej do idealizującej metody. To znaczy nie utrzymuje się empirycznej metody do końca, wątpliwości graniczne przecina się konwencją ${ }^{79}$.

Tak jak intuicyjność etapu empirycznego skutkuje nieostrością typu, tak konwencjonalizm etapu idealizującego może skutkować jego nieużytecznością. Źle dokonana idealizacja może zaowocować typem zbyt wąskim, np. inwariantnym ${ }^{80}$ lub stałym ${ }^{81}$. Dlatego do poprawnego wyróżnienia typów niezbędne są: wiedza przedmiotowa (np. dotycząca architektury, antropologii, biologii), wnikliwa obserwacja, inicjatywa badawcza (typy nie są bezpośrednio dane) oraz doświadczenie i umiejętność właściwej idealizacji.

\section{Teoria}

Wyniki tych czynności formułujemy w postaci twierdzeń. Tatarkiewicz wyróżnia twierdzenia jednostkowe (stwierdzające zachodzenie indywidualnego zjawiska) oraz twierdzenia ogólne (dotyczące pewnej klasy zjawisk). Twierdzenia ogól-

79 W. Tatarkiewicz, O filozofii i sztuce, dz. cyt., s. 120.

80 „[Typ] trzeba formułować tak, by było w nim miejsce na «warianty» typu, lub (terminologia różna, rzecz ta sama) na cechy «alternatywne». Wtedy można określać typ także w postaci «Typ $\mathrm{X}$ jest albo A, albo B»”. Tamże, s. 121-122.

81 „Na ogół jednak ewolucja jest normalnym losem rzeczy, który nie omija i typów, dlatego niepodobna tak wąsko ujmować pojęcia typu, aby obejmowało same typy stałe. A raczej: w teorii można to uczynić, ale w praktyce pojęcie typu staje się wtedy bezużyteczne, bo zbyt wąskie". Tamże, s. 122. 
ne dzieli na a) definicyjne (jeśli wymieniają takie własności zjawisk, że można po nich rozpoznać każdy przedmiot tej klasy) oraz b) teorie (jeśli opisują i tłumaczą przedmioty danej klasy).

Feliks Jaroński dał niegdyś (O filozofii, 1812) prosty przykład odróżnienia definicji i teorii: gdy o powietrzu mówimy, że jest to „gaz otaczający kulę ziemską", to jest to definicja, gdy zaś mówimy, że jest ono mieszaniną azotu i tlenu, to jest to już teoria ${ }^{82}$.

Pojęcie teorii funkcjonuje $\mathrm{w}$ wąskim i szerokim sensie ${ }^{83}$. W szerokim sensie teorię stanowi zespół tez obejmujących definicję i charakterystyki klas przedmiotów, niekiedy nazywa się je „koncepcjami”. W wąskim sensie teorie opisują i tłumaczą własności klas przedmiotów.

Teorie są punktem końcowym czynności naukotwórczych i stanowią scalenie naszej wiedzy o danej klasie przedmiotów ${ }^{84}$. Tworzymy je, ponieważ są potrzebne, nawet gdy wcześniej czy później okazują się być nieprawdziwe. Gdy dotychczasowa teoria okaże się nieprawdziwa, możemy ją uzupełnić, zmienić, odrzucić dla nowej teorii lub ograniczyć jej zasięg. Jak stwierdza Tatarkiewicz:

Prawdziwość ich może być uratowana, gdy się zawęzi ich zakres albo ogólniejszemu pojęciu da definicję alternatywną. Historyk wie, że ogólne teorie sztuki czy piękna, które zawodziły, okazały się jednakże trafnymi teoriami dla węższego zakresu, dla niektórych działów sztuki, niektórych postaci piękna. W ogólnym bezwzględnym sformułowaniu były omyłkami, wyjaśniają jednakże pewne postacie piękna i sztuki i w tym sensie są pożyteczne ${ }^{85}$.

Jacek Jadacki wyszczególnia u Tatarkiewicza następujące rodzaje twierdzeń teoretycznych: a) tezy empiryczne (stwierdzające istnienie), b) tezy rejestrujące (coś jest obowiązkiem), c) tezy normatywne (należy to robić), d) tezy podstawowe (opis dziedziny teorii), e) tezy pochodne (np. prawa) ${ }^{86}$.

Szczególnymi rodzajami teorii są teorie dotyczące wytworów działalności ludzi, bowiem nie tylko mogą stanowić odwzorowanie badanej rzeczywistości, lecz mogą na nią również wpływać lub też przewidywać. $Z$ kolei w niektórych

\footnotetext{
82 W. Tatarkiewicz, Dzieje sześciu pojęć, dz. cyt., s. 18.

83 J.J. Jadacki, Metodologia w ujęciu Władysława Tatarkiewicza, dz. cyt., s. 81.

84 W. Tatarkiewicz, Dzieje sześciu pojęć, dz. cyt., s. 398.

85 Tamże, s. 399.

86 J.J. Jadacki, Metodologia w ujęciu Władysława Tatarkiewicza, dz. cyt., s. 81.
} 
dziedzinach wiedzy wartościowe poznawczo może być budowanie teorii krańcowych, wywołujących sprzeciw i kontrowersyjnych, w tym celu by poprzez ich zakwestionowanie, ograniczenie lub korektę zbliżyć się do prawdy lub skonstruować prawdziwe teorie szczegółowe ${ }^{87}$. Tym bardziej że:

[...] od teorii do teorii przebiegają dzieje wiedzy o pięknie i sztuce, formie i twórczości. Nie inaczej niż to się dzieje w naszej wiedzy o przyrodzie, człowieku i społeczeństwie ${ }^{88}$.

\section{Metody historyczne}

Najobszerniejsza część poglądów metodologicznych Tatarkiewicza dotyczy metod rekonstrukcji, opisu i wyjaśniania faktów historycznych, jednak większość uwag metodologicznych, jakie Tatarkiewicz czynił w odniesieniu do pracy naukowej historyka, czynił przez pryzmat swojej pracy badawczej na polu historii sztuki i filozofii, jestem jednak przekonany, że wiele $\mathrm{z}$ tych uwag może być uogólnionych do postaci twierdzeń o metodologii historii w ogóle. Uwagi ściśle związane z metodologią historii filozofii rekonstruuję jako oddzielny fragment.

\section{Ogólna metodologia historii}

Tatarkiewicz zauważa że historia - chociaż jest nauką empiryczną - to przez dwuznaczność w jej pojęciu ${ }^{89}$ była różnie umiejscawiana w klasyfikacji nauk, może bowiem być pojmowana bądź jako nauka idiograficzna (ustalająca i wyjaśniająca fakty jednostkowe, indywidualne) ${ }^{90}$, bądź (tak jak pojmował ją Tatar-

W. Tatarkiewicz, Dzieje sześciu pojęć, dz. cyt., s. 397.

Tamże, s. 398-399.

89 „Jest bowiem pewna dwuznaczność w pojęciu historii: bądź oznacza ona - szeroko - wszelkie studium temporis acti, bądź też - po zwężeniu - oznacza specjalne badanie genetyczne. Jeśli używa się pojęcia wąsko, tylko wywód genetyczny uważając za «historyczny», to ex definitione klasyfikację usuwa się poza obręb historii. Ale to nie dotyczy zwyklejszego, szerszego pojęcia historii". W. Tatarkiewicz, O filozofii i sztuce, dz. cyt., s. 145.

90 Tak definiował przedmiot historii między innymi Marceli Handelsman. Tenże, Historyka, Neriton, Warszawa 2010, s. 6. 
kiewicz) jako nauka typologiczna, która oprócz ustalania faktów jednostkowych również je wyjaśnia i porządkuje poprzez wyróżnianie typów w czasie.

Takie rozumienie historii stanowi opozycję dla faktycyzmu i genetyzmu, poglądów, które postulują, że zadanie historii zawiera się bądź w biernym stwierdzaniu i opisie faktów, bądź w samym ich ustalaniu i wyjaśnianiu ${ }^{91}$. Swój pogląd na rolę historyka $\mathrm{w}$ badaniach przedmiotowych Tatarkiewicz określa mianem „interwencjonizmu historycznego”, uwypuklając tym samym aktywną i twórczą rolę podmiotu możliwą do zaobserwowania na każdym z etapów pracy, polegającej na: a) wyborze faktów, czyli ich segregacji i selekcji dokonanej przez pryzmat wiedzy o tym, czy należą do badanego zjawiska, oraz oceny ich istotności, b) interpretacji faktów, a zatem wskazania ich znaczenia dla badanego zjawiska, c) scalaniu faktów, czyli ustaleniu relacji pomiędzy faktami pierwszo- i drugorzędnymi, d) porządkowaniu faktów (typologii, czyli grupowaniu wedle ich podobieństwa oraz periodyzacji, tj. określenia ich ram czasowych), e) powiązaniu faktów (genealogii i eksplikacji, czyli wskazaniu zależności względem faktów wcześniejszych oraz późniejszych). Przy czym w historii filozofii interwencja historyka przybiera także szóstą postać, czyli f) korektę faktów, przejawiającą się w udoskonaleniu lub krytyce poglądów badanego filozofa ustalonych niewłaściwie ${ }^{92}$ ). Każdy z powyższych etapów wymaga inicjatywy historyka, lecz ta może przyjąć różne formy i rozmiary, nadto niekiedy uzależniona jest od woli badacza, a innym razem - nieunikniona. Przykładami tego są interpretacja i periodyzacja.

Tatarkiewicz zwraca uwagę, że dla pracy historyka znajomość teraźniejszości stanowi ułatwienie, bowiem „późniejsze dzieje rzucają światło na wcześniejsze"93. Zatem:

[...] historyk może z korzyścią uwzględniać czas późniejszy przy interpretowaniu wcześniejszego; może, a nie musi. Nie jest to konieczne, ale jest pożyteczne, w wielu wypadkach korzystne i historykowi pomocne ${ }^{94}$.

\footnotetext{
$91 \quad$ Tamże, s. 23.

92 W historii filozofii również udoskonaleniu lub krytyce twierdzeń filozofów poddawanych rekonstrukcji.

93 W. Tatarkiewicz, O filozofii i sztuce, dz. cyt., s. 164.

94 Tamże, s. 160. Tatarkiewicz wypowiada się tu o możliwości korzystania z wiedzy o przyszłości, jednak w odniesieniu do historii idei pisze: „Uwzględnianie faktów późniejszych przy badaniu dawniejszych wydaje się dla historyka nie tylko dopuszczalne, ale nawet korzystne, niekiedy niezbędne”. Tamże, s. 159.
} 
Porównywanie faktów historycznych względem im późniejszych ułatwia ich zrozumienie i ocenę, a niekiedy nawet dobór i opis. Nadto historyk, będąc niejako pomostem pomiędzy przeszłością a teraźniejszością, może zaproponować takie opracowanie i interpretację niekiedy bardzo odległych faktów historycznych, by stały się zrozumiałe dla współczesnych odbiorców, a to możliwe jest tylko dzięki wykorzystaniu wiedzy o współczesności ${ }^{95}$. Dobrowolność korzystania z wiedzy o teraźniejszości uwidacznia woluntarystyczny charakter interwencji historyka przynajmniej w pewnych aspektach jego pracy.

Odmienna sytuacja ma miejsce w periodyzacji, która zakłada interwencję, bowiem $\mathrm{z}$ zasady jest konwencjonalna (przynajmniej do pewnego stopnia), lecz nie dowolna - nawet jeśli nie wyznaczają jej względy obiektywne, to robi to cel jej przeprowadzenia ${ }^{96}$. Periodyzacja może pełnić cztery funkcje: a) przygotowawczą (pozwala wstępnie uporządkować materiał badań), b) poznawczą (umożliwia poznanie przebiegu dziejów), c) heurystyczną (pomaga w zrozumieniu procesów historycznych) oraz d) porównawczą (pozwala porównywać przebieg dziejów na różnych terenach czy w różnych dziedzinach). Przy czym:

Historyk, który uważa, że podziały, klasyfikacje, periodyzacje są zabiegiem sztucznym i subiektywnym, może je ostatecznie pominąć i przedstawiać dzieje jako następstwo jednostkowych faktów. Uniknie wtedy wielu błędów i dowolności. Ale zarazem zamknie sobie drogę do lepszego zrozumienia dziejów ${ }^{97}$.

Kolejny przykład interwencjonizmu historycznego to selekcja zagadnień badawczych ${ }^{98}$ dokonywana przez pryzmat istotności tematu dla rozwoju epoki ${ }^{99}$,

95 Marceli Handelsman zwraca uwagę, że dzieje się to dlatego, że przedmioty przeszłości posiadają znaczenie symboliczne zarówno w odniesieniu do przeszłości, jak i do teraźniejszości, bez względu na czasowe oddalenie przeszłości od teraźniejszości. Tenże, Historyka, dz. cyt., s. 270-271.

96 „Periodyzacja konwencjonalna z natury rzeczy jest najbardziej celowa, gdy jest najprostsza i schematyczna, właśnie jak siatka kreślarska”. W. Tatarkiewicz, Pisma zebrane, Droga do filozofii i inne rozprawy filozoficzne, dz. cyt., s. 91.

97 Tamże, s. 93.

98 „Historycy wybierają tematy, które mają za ważne; ważne zaś jest to, co w ten czy inny sposób jest wielkie. Ale historycy wybierają również tematy, które są im bliskie. W. Tatarkiewicz, Parerga, Państwowy Instytut Wydawniczy, Warszawa 1978, s. 132.

99 „A jednak: także przy takim nastawieniu historyk liczy się, musi się liczyć z tym, co bliskie. Nie z tym, co jemu osobiście bliskie, natomiast z tym, co było bliskie epoce, którą studiuje”. Tamże, s. 133. 
dla rozwoju dziejów w ogóle ${ }^{100}$ oraz sposobów i efektów recepcji idei. Historyk dokonuje tej selekcji, mając za przedmiot zarówno jednostki, jak i całe grupy lub społeczności.

Stąd też Tatarkiewicz wyszczególnia następujące rodzaje twierdzeń historycznych: 1) twierdzenia o faktach - bezpośrednie (x powiedział, że p), 2) twierdzenia pochodne z faktów - pośrednie, które można podzielić na: a) ogólne (wszyscy w czasie t twierdzili, że x), b) eksplikacyjne (x powiedział, że p pod wpływem y) oraz c) oceniające (pogląd x-a był przełomowy), a także 3) twierdzenia pomocnicze (np. dotyczące historii ludzi, nie idei, sztuki czy wiedzy) ${ }^{101}$.

W praktyce historiograficznej występują wszystkie rodzaje twierdzeń, jednak nie występują w równych proporcjach, co związane jest bezpośrednio z indywidualnym przekonaniem historyka o zależności pomiędzy opisową, wyjaśniającą, interpretatywną i oceniającą funkcją historiografii. Tym bardziej że historyk w swojej pracy naukowej powinien kierować się dwoma postulatami: a) postulatem roboty czystej (przyjmując pewną perspektywę, należy się jej trzymać, postulat historii jednorodnej), b) postulatem roboty kompletnej (tłumacząc dany fakt, należy uwzględnić wszystkie czynniki, które mogły mieć na niego wpływ). Tatarkiewicz zauważa, że często postulaty te są ze sobą zantagonizowane, co widać szczególnie w historii filozofii.

\section{Historia filozofii}

Zagadnieniem rozgraniczającym ogólną metodologię historii od historii filozofii jest problematyka interpretacji faktu bezpośredniego. W historii filozofii twierdzenie: „x powiedział, że p” można interpretować następująco: a) psychologicznie: „w umyśle x powstała myśl, że p i x ją wygłosił”, b) fizycznie: „x sporządził napis p”, c) logicznie: „x stwierdził, że p jest prawdą”. Według Tatarkiewicza interpretacja fizyczna ma charakter tylko pomocniczy, stąd też można ten podział ograniczyć do dwóch pozostałych, wyróżniając dwie koncepcje historii filozofii, które Tatarkiewicz nazywa: 1) Historią filozofii (zajmuje się twierdzeniami, wytworami); 2) Historią filozofów (zajmuje się myślami, czynnościami). W praktyce

\footnotetext{
100 „Tak olbrzymia literatura o Platonie czy Arystotelesie, św. Tomaszu czy Kancie jest naturalnym skutkiem tego, że byli wielcy, a zarazem wielu historykom bliscy". Tamże, s. 132.

101 Podobny wymóg połączenia faktów w opis dziejów, tak by z faktów jednostkowych wyłonił się obraz rzeczywistości przeszłej, stawia Marceli Handelsman. Tenże, Historyka, dz. cyt., , s. 200.
} 
oba te sposoby przeplatają się ze sobą, ponieważ konsekwentna realizacja jednego z nich przeczyłaby któremuś z postulatów pracy historyka.

„Historia filozofii jest historią odkrywania pojęć”"102, a dokładnie sposobów, w jaki kształtowały się i ewoluowały na przestrzeni wieków, stąd też:

Historyk musi walczyć z synonimami i homonimami; w tekstach, jakie doń doszły, znajduje nieraz wiele wyrazów o tym samym znaczeniu i wiele znaczeń tego samego wyrazu. Znajduje też pojęcia tak splątane, że staje wobec zadań podobnych do obowiązków leśnika, który w gęstwinie leśnej musi rąbać ścieżki, albo je przynajmniej prostować ${ }^{103}$.

Problem ten dotyczy nie tylko zagadnień czy prądów myślowych, lecz także niekiedy nawet pism jednego myśliciela, ponieważ: „zdarza się, że nieraz ma on wiele znaczeń dla jednego terminu lub wiele terminów dla jednego pojęcia”104. Co więcej, niekiedy główne myśli i twierdzenia potrafią być wyrażone tak niejasno, że niezbędny jest ktoś, kto nada im jasny i wyraźny kształt, ponieważ nie tylko: „ważne co filozof myślał o swoich tezach, ale jeszcze ważniejsze co te tezy zawierają, a mógł nie wypowiedzieć ich jasno, nie wyciągnąć wszystkich konsekwencji” 105 .

Tatarkiewicz wyróżnia dwa sposoby analizy występujące w historii filozofii: 1) Krytyka historyczna - „włączyć określonego myśliciela w ciąg zagadnień i rozwiązań - postawić przed sądem historii” ${ }^{106}$, 2) Analiza immanentna - „metoda, która zrazu abstrahuje od powiązań historycznych, aby w izolowanym rozpamiętywaniu jakiegoś myśliciela ustalić jego wewnętrzne drogi myśli i uchwycić je w ich czystości i w ich konsekwencjach [...] jedność i konsekwencja w systemie o charakterze naukowym musi mieć dlań walor zasady heurystycznej”107.

Interwencja historyka w historii filozofii ma za podstawę w pierwszej kolejności selekcję faktów z uwagi na oryginalność, postępowość, prawdziwość lub wpływowość poglądów myśliciela. Odbywa się to poprzez zestawienie jednych faktów z innymi, lecz niekiedy: „same fakty nie dają dostatecznej podstawy do

\footnotetext{
102 W. Tatarkiewicz, Układ pojęć w filozofii Arystotelesa, dz. cyt., s. 15.

103 Tenże, Dzieje sześciu pojęć, dz. cyt., s. 19

104 Tenże, Układ pojęć w filozofii Arystotelesa, dz. cyt., s. 17.

105 Tenże, Droga do filozofii i inne rozprawy filozoficzne, dz. cyt., s. 70.

106 Tenże, Układ pojęć w filozofii Arystotelesa, dz. cyt., s. 16.

107 Tamże, s. 16-17.
} 
interpretacji, korekty czy selekcji" ${ }^{108}$, stąd też historyk filozofii powinien sam być filozofem. Dzięki znajomości pojęć i zagadnień filozoficznych jest w stanie lepiej dokonywać selekcji i opracowywania faktów, zaś dzięki przyjęciu założeń pewnego systemu filozoficznego może dokonywać interpretacji i krytyki. Stąd też właściwym pytaniem nie jest, czy historyk filozofii powinien być filozofem, lecz jakim systemem założeń filozoficznych powinien się kierować w swojej pracy. Możliwości są tu dwie: albo przyjmuje jeden system, który uznaje za prawdziwy i z jego perspektywy ocenia pozostałe, albo przyjmuje założenia każdego filozofa, którego opracowuje.

Tatarkiewicz zauważył, że prądy intelektualne, idee filozoficzne, rozwijają się według pewnego schematu:

Jest zrozumiałe, że każdy cykl rozpoczynał się od okresu przygotowania, analizy, zbierania elementów, z których okres późniejszy zestawiał swe systemy. Nie jest też dziwne, że w każdym cyklu prędzej czy później przychodził okres zatrzymania pracy poszukiwawczej, będący za to czasem stosowania, rozwijania, szczegółowego opracowywania zdobytych poprzednio prawd, krótko mówiąc, okres „szkół” filozoficznych. Doświadczenie historyczne (a nie aprioryczna spekulacja) wskazuje, że w dziejach filozofii, przynajmniej europejskiej, przychodzą stale te cztery okresy: analizy, systemów, krytyki, szkół ${ }^{109}$.

Cykle rozwojowe nie są niczym niezwykłym, bowiem występują zarówno w historii filozofii, jak i całej historii ludzkości ${ }^{110}$. Rozpoczynają się na drodze ewolucji (stopniowego formowania pojęć, zrastania nowych ze starymi itp.) lub rewolucji (wstrząsu, przewrotu prowadzącego do zerwania ciągłości kształtowania się pojęć). W obu przypadkach prowadzą do wyodrębnienia się pewnego typu myśli, który przeważa w tym okresie, stając się dla niego charakterystycznym. Nie oznacza to, że inne typy myślenia w ogóle wtedy nie występują, lecz że nie są przedmiotem zbiorowego wysiłku, będąc rozwijanymi przede wszystkim przez jednostki, nie zaś szkoły. Najogólniejszymi typami występującymi w historii filozofii są minimalistyczne i maksymalistyczne jej ujęcia, następujące po

\footnotetext{
108 W. Tatarkiewicz, Droga do filozofii i inne rozprawy filozoficzne, dz. cyt., s. 53.

109 Tamże, s. 107.

110 „Okresy historyczne nie zawsze mają taką samą naturę. Jedne są dalszym ciągiem poprzednich, inne zaś zaczynają od nowa cykl rozwojowy; jedne powstają na skutek przemian, inne na skutek przewrotów. Dotyczy to okresów filozofii tak samo jak innych działów historii”. W. Tatarkiewicz, Pisma zebrane, Droga do filozofii i inne rozprawy filozoficzne, dz. cyt., s. 93.
} 
sobie w dziejach jako sprzeciw i przeciwwaga dla aktualnie przeważającego typu myślenia.

Aktualną sytuację dziejową Tatarkiewicz charakteryzuje jako nieoczekiwany czas stabilizacji pojęć i teorii, który może się rychło skończyć przewrotem, gdyż:

Wielu ludzi dzisiejszych ma poczucie, że znajdują się w punkcie zwrotnym. I odpowiada im to: sami chcieliby być twórcami przewrotu. Przewrotów niemało bywało w przeszłości, ale - nie były w tym stopniu zamierzone, świadomie przygotowane. Bywały właśnie niezamierzone, dokonywały się raczej pod przymusem wewnętrznym, często bez świadomości, że są przewrotami. Historyk zna niewiele precedensów dla chwili obecnej, trudno mu też przez analogię przepowiedzieć, jakie będą etapy następne; nie ma w szczególności doświadczenia co do tego, czy przewrót świadomy i umyślny („niech będzie inaczej niż było") jest przewrotem głębszym i o dłuższym działaniu ${ }^{111}$.

\section{Pisanie artykułów}

Pisma Tatarkiewicza wyróżnia nie tylko przejęty od Twardowskiego ${ }^{112}$ jasny i precyzyjny tok wykładu, stanowiący cechę rozpoznawczą i jeden z głównych postulatów metodologicznych Szkoły Lwowsko-Warszawskiej, lecz także ponadprzeciętna wartość literacka i estetyczna, stąd też pozwolę sobie przekazać kilka wskazówek warsztatowych, które autor Historii filozofii zawarł w swoich tekstach:

1. Pisz jasno i prosto, ponieważ „aby twierdzenie czy pojęcie przeszło z umysłu piszącego (czy mówiącego) do umysłu czytającego (czy słuchającego), musi być dokonana pewna praca, a sądzę, że jest lepiej, gdy wykona ją piszący (czy mówiący)”113, tym bardziej że „sprawa stylu to sprawa rozumienia tego co się pisze"114.

W. Tatarkiewicz, Dzieje sześciu pojęć, dz. cyt., s. 394.

112 „Przyznam się, że pisząc ją [Historię filozofii], myślałem, czy posiada dostateczną jasność i dokładność myśli, układu, wysłowienia się, której przykłady Pan Profesor dał i której przeto ma prawo od polskich pisarzy filozoficznych wymagać", cyt. za: R. Kleszcz, W. Tatarkiewicz. Uwagi metafilozoficzne, dz. cyt., s. 34 .

113 T. i W. Tatarkiewiczowie, Wspomnienia, dz. cyt., s. 175.

114 Cyt. za: Wspomnienia uczestnika seminarium prowadzonego przez prof. Władysława Tatarkiewicza w latach 1947-1950, w: Władysław Tatarkiewicz w siedemdziesięciolecie I wydania „Historii Filozofii", dz. cyt., s. 28. 
2. Dbaj o tok układu, gdyż „nie trzeba domagać się od uczonego genialnych pomysłów, ale można i trzeba oczekiwać i domagać się ładu”"115, dlatego „,dobrze jest w końcu książki wrócić do myśli, od której się rozpoczynała"116.

3. Dostosuj formę i styl wypowiedzi do odbiorców, ponieważ „inna forma jest dobra $\mathrm{w}$ żywej mowie, a inna w pisaniu, ogłaszaniu, utrwalaniu myśli”"117, tym bardziej gdy trzeba „bardzo dużą ilość spraw, faktów, myśli ująć w sposób możliwie prosty, a nie zniechęcający czytelnika"118 lub słuchacza.

4. Pisz intersująco: „nie lubię, gdy mnie kto nudzi, staram się też innych nie nudzić"119, by to osiągnąć, trzeba „domagać się od uczonego (nie tylko od artysty) smaku, inaczej praca jego będzie trywialna"120, ponieważ bez inteligencji i bystrości umysłu „humanistyka staje się nudą, pewno w przyrodoznawstwie, matematyce, nawet technice jest podobnie"121.

\section{Podsumowanie}

Metodologia Tatarkiewicza ma charakter opisowy, co uwidacznia się szczególnie w metodologii historii stanowiącej opis praktyki badawczej budowania narracji historycznej. Pisma autora Historii filozofii pozbawione są teoretycznych rozważań normatywnych prowadzonych z pozycji ściśle filozoficznych, co wraz z jego doświadczeniem w obu dyscyplinach stanowi niewątpliwą zaletę na tle innych koncepcji metodologii historii, pisanych bądź przez filozofów bez praktyki historycznej, bądź przez historyków bez adekwatnej wiedzy filozoficznej.

Jednocześnie w odniesieniu do poglądów Tatarkiewicza nieuchronnie pojawiają się pytania o ich nowatorskość oraz włączenie tychże do prądów lub nurtów myślowych ówczesnej nauki. Na pierwsze pytanie odpowiada sam Tatarkiewicz ${ }^{122}$ :

\footnotetext{
T. i W. Tatarkiewiczowie, Wspomnienia, dz. cyt., s. 179.

W. Tatarkiewicz, Dzieje sześciu pojęć, dz. cyt., s. 398.

Tenże, Pisma zebrane, Droga do filozofii i inne rozprawy filozoficzne, dz. cyt., s. 7.

Tamże, s. 6.

Teresa i W. Tatarkiewiczowie, Wspomnienia, dz. cyt., s. 175.

Tamże, s. 178-179

Tamże, s. 179.

22 Jak zwraca uwagę J.J. Jadacki, nie powstawała żadna historia metodologii, stąd też w ocenie nowatorskości trzeba zaufać Tatarkiewiczowi. Zob. J.J. Jadacki, Metodologia w ujęciu Władysława Tatarkiewicza, dz. cyt., s. 89.
} 
Tematy ogłoszonych tu rozpraw są bezosobiste, ale osobisty jest ich dobór, a jeszcze bardziej ich tezy. A więc, że: naturalny, pozanaukowy obraz świata nie jest fałszywy; w nauce pojęcie typu jest nie mniej użyteczne niż pojęcie prawa naukowego; periodyzacja jest zawsze w pewnym stopniu umowna; praca historyka nigdy nie może być bierna, jego interwencja jest nieuchronna; podstawowe zagadnienia etyki są wielorakie i sąd o słuszności ma inne właściwości niż sąd o dobru; niektóre dobra osiąga się pewniej, gdy się o nie zabiega; wieloznaczność nazw jest istotną sprawą nie tylko semiotyki, ale etyki i estetyki; trudności tych dziedzin filozofii zmuszają do stosowania szczególnych zabiegów i pojęć, definicji alternatywnych, teorii pluralistycznych ${ }^{123}$.

Oraz w odniesieniu do proponowanej przez niego klasyfikacji nauk:

Jednakże klasyfikacja taka, jaka tu jest proponowana, nie była dotychczas, jak się zdaje, stosowana. Grupy nauk, jakie oddziela, bywały wprawdzie oddzielane, ale na innej podstawie ${ }^{124}$.

Z kolei w odniesieniu do przynależności Tatarkiewicza oraz jego poglądów metodologicznych do określonego prądu myślowego narosło wiele sporów. Dla przykładu: L. Kołakowski oraz T. Kroński określili go neokantystą ${ }^{125}$, B. Kieszkowski - pozytywistą, Z. Kuderowicz umiejscawia jego poglądy w nurcie humanistyki rozumiejącej ${ }^{126}$, A.M. Nowik wskazuje na neopozytywistyczne rozumienie faktu historycznego ${ }^{127}$ oraz możliwą zgodność z niektórymi poglądami neotomisty E. Gilsona ${ }^{128}$, B. Dembowski zwraca uwagę, że „Tatarkiewicz podejmował w swoich badaniach zagadnienia [...], których nie można rozwiązać przy pomocy metod logicznych, uważanych za jedynie słuszne przez neopozytywizm"129, zaś J. Pelc opisuje metodologię Tatarkiewicza ogólnie jako: „semiotyzm (wraz z zabiegami klasyfikacyjnymi), historyzm oraz typologizm”130, z kolei R. Palacz stwierdza, że: „inni w postawie filozoficznej Tatarkiewicza nie znaleźli nic więcej

\footnotetext{
W. Tatarkiewicz, Pisma zebrane, Droga do filozofii i inne rozprawy filozoficzne, dz. cyt., s. 7-8. Tamże, s. 62.

125 Za R. Palacz, W. Tatarkiewicz jako historyk filozofii, dz. cyt., s. 490.

126 Za Z. Kuderowicz, Czy „Historia filozofii” należy do humanistyki rozumiejącej?, dz. cyt., s. 44.

127 A.M. Nowik, Historiografia Władysława Tatarkiewicza w kontekście sporów metodologicznych, dz. cyt., s. 502.

128 Tamże, s. 498.

129 B. Dembowski, Wspomnienia uczestnika seminarium prowadzonego przez prof. Władysława Tatarkiewicza w latach 1947-1950, dz. cyt., s. 37.

130 Za. R. Kleszcz, W. Tatarkiewicz. Uwagi metafilozoficzne, dz. cyt., s. 38.
} 
niż ostrożność, realizm, humanizm, historyzm, subiektywizm, który uniemożliwiał weryfikację wniosków, semantyzm, pluralizm"131. Natomiast sam Tatarkiewicz pisze na ten temat następująco:

Zdaję sobie sprawę, że szczególnie trudne było włączenie mnie do jakiegoś kierunku i szkoły. Studia uniwersyteckie odbywałem w uniwersytecie, gdzie istniała rzeczywiście szkoła filozoficzna. Ale już w pracy doktorskiej wyłamałem się z tej szkoły. I potem do żadnej nie wszedłem (jeśli nie liczyć uznania dla metodologicznej szkoły lwowskiej). Nawet nie zastanawiałem się, gdzie jest moje miejsce na mapie filozoficznej XIX wieku. Gdyby mnie kto naciskał, to prawdopodobnie powiedziałbym, że blisko Brentana i realistów brytyjskich. Moja znajomość szkoły badeńskiej jest znikoma. Kant jest dla mnie wielkim myślicielem, ale takim, z którym niewiele mam ostatecznie wspólnego ${ }^{132}$.

Mając na uwadze rozbieżność powyższych ocen, można wysnuć wniosek, że trudność w zaklasyfikowaniu poglądów metodologicznych Tatarkiewicza wynika z ich eklektycznego charakteru, który pozwala wskazywać podobieństwa względem różnych szkół i prądów myślowych. Gdy przyjmie się koncepcję metodologii historii Tatarkiewicza, jego poglądy będą zjawiskiem nietypowym, można odnaleźć w nich bowiem podobieństwa względem wielu typów.

Szerokie rozumienie opisu, uwypuklenie badań filologicznych i semiotycznych, nacisk na badania porównawcze, a także podział na historię filozofii i historię filozofów odpowiada tradycyjnej biografii i doksografii filozoficznej uprawianej już od czasów Diogenesa Laertiosa. Mocną stroną tejże jest analiza immanentna, którą Tatarkiewicz zastosował w rozprawie doktorskiej, a która stanowi stosowany do dziś przykład (krytykowanej niegdyś przez Hegla) metody opisowej.

Z kolei wczesne stosowanie ocen w badaniu historycznym, wskazywanie na pewne regularności w rozwoju filozofii w postaci cyklów rozwojowych czy tė podkreślenie metody prób i błędów w tworzeniu teorii wraz z uznaniem częściowej prawdziwości niektórych $\mathrm{z}$ nich nawiązuje do heglowskiej metody wartoś-

131 R. Palacz, W. Tatarkiewicz jako historyk filozofii. Kilka uwag, dz. cyt., s. 490.

132 W. Tatarkiewicz, Listy do Ryszarda Wiśniewskiego, oprac. R. Mordarski, „Filo-Sofija” 2011, nr 13-14(2-3), s. 716. 
ciującej, dokładnie recepcji tejże w duchu neokantyzmu marburskiego ${ }^{133}$. Przy czym akceptacja dla pluralizmu wartości i teorii świadczy, że jest to jej druga (pozbawiona skrajności) odmiana. Jak zauważył Z. Kuderowicz, taką metodą posłużył się Tatarkiewicz, pisząc Historię filozofii ${ }^{134}$.

Zaprezentowanie postulatu roboty kompletnej w pracy historycznej, a zatem konieczności nawiązywania do innych dziedzin kultury wraz z wielokrotnymi (chociaż nie pierwszoplanowymi) odniesieniami dotyczącymi budowania szeregów genetycznych, a zatem do wyjaśniającej roli nauki i historii, a także ukazanie twórczej aktywności historyka filozofii w tworzeniu narracji historycznej pozwala wskazać na podobieństwo metodologii Tatarkiewicza względem metody wyjaśniającej, której w swych pracach dał przykład (przywoływany przez Tatarkiewicza) Kuno Fischer ${ }^{135}$.

Natomiast ujęcie historii jako nauki typologicznej wraz z koncepcją interwencji historyka zbliża Tatarkiewicza do metody rozumiejącej Diltheya ${ }^{136}$, która kładzie nacisk na konieczność zaprezentowania interpretacji faktów filozoficznych wobec „bezgranicznej wieloznaczności materiału filozoficznego” ${ }^{137}$.

Powyższa interpretacja poglądów Tatarkiewicza zgodna jest $\mathrm{z}$ jego samookreśleniem jako „zbieracza myśli”. Ukazuje autora Historii filozofii jako myśliciela, który czerpał z różnych szkół i stylów filozoficznych to, co w jego przekonaniu warte było zaczerpnięcia, przyjmując za kryterium decydujące o wyborze przekonanie o częściowej prawdziwości każdej teorii. Dążył tym samym do wypracowania własnego ujęcia metodologii historii filozofii, która dzięki swojemu eklektycznemu pluralizmowi wolna będzie od głównych zarzutów, jakie stawiano poszczególnym metodom. Niestety pełnego ujęcia tej problematyki nie dał nigdy, lecz za sprawą koncepcji interwencjonizmu historycznego podtrzymał ogólny pogląd, że sama erudycja nie wystarcza do realizacji zadań historii filozofii, musi bowiem zostać uzupełniona o „metodę w szerokim znaczeniu (obejmującą cele poznawcze i całą wiodącą do nich strategię analityczną)"138.

133 A.M. Nowik, Historiografia Władysława Tatarkiewicza $w$ kontekście sporów metodologicznych, dz. cyt., s. 499.

134 Z. Kuderowicz, Przegląd metod historii filozofii, dz. cyt., s. 13.

135 W. Tatarkiewicz, O filozofii i sztuce, dz. cyt., s. 48.

136 Z. Kuderowicz, Czy „Historia filozofii” należy do humanistyki rozumiejacej?, dz. cyt., s. 45.

137 W. Dilthey, cytat za: W. Tatarkiewicz, O filozofii i sztuce, dz. cyt., s. 42.

138 Zob. Z. Kuderowicz, Przegląd metod historii filozofii, dz. cyt., s. 5. 
Niestety pomimo niewątpliwych zalet, z uwagi na swoją fragmentaryczność, Tatarkiewiczowskie ujęcie nie może stanowić opisowej podstawy do zbudowania pełnoprawnej normatywnej oferty metodologicznej. Refleksja nad propozycjami Tatarkiewicza uwidacznia następujące problemy:

1. Problem badania zjawisk atypowych. O ile zjawiska typowe można badać przez wyróżnienie i włączenie do typu, o tyle zjawiska nietypowe wymykają się takiemu porządkowaniu. Powstaje pytanie o rolę i wartość poznawczą tych zjawisk oraz potencjalne metody ich badania.

2. Rozdźwięk pomiędzy postulatem bazowania na faktach historycznych a postulatem zrozumienia poglądów filozofa lepiej, niż on sam je rozumiał. Tatarkiewicz, chociaż świadom był paradoksalności takiego ujęcia, nie rozstrzygał, czy co do zasady należy dać prymat wypowiedziom bezpośrednim danego filozofa, czy może poglądom jego badaczy i własnym interpretacjom.

3. Brak opisu procedury uzgadniania niezgodności. Często w tekstach filozoficznych jednego autora można odnaleźć niezgodności ${ }^{139}$, znacząco utrudniające interpretację poglądów i niekiedy stanowiące podstawę dla krytyki wewnętrznej. Koncepcja interwencjonizmu Tatarkiewicza nie przesądza, czy co do zasady takie przypadki należy pominąć, uzgodnić, przeciwstawić czy uwypuklić.

4. Stosunkowo mało uwagi Tatarkiewicz poświęca zagadnieniu źródła historycznego w historii filozofii (co też stało się przyczyną powstania polemicznego artykułu R. Ingardena, O przedmiocie historii filozofii). Nie podejmuje również zagadnień krytyki zewnętrznej i wewnętrznej tekstów, rękopisów, a także pracy nad archiwami, chociaż był przekonany o wartości takiej pracy dla rozwoju historii.

5. Brak wyraźnych kryteriów selekcji faktów. Bez wątpienia powinny to być kryteria intersubiektywnie komunikowalne i sprawdzalne, lecz Tatarkiewicz nie określa dokładnie, czym należy się kierować, oceniając słuszność, prawdziwość, wpływowość czy oryginalność poglądów ${ }^{140}$.

139 Dotyczy to również Tatarkiewicza: „[...] gdy podejmuję jakiś temat, to nie odczytuję tego, co poprzednio na ten sam i zbliżone tematy pisałem, więc łatwo mogą się znaleźć niezgodności”. W. Tatarkiewicz, Listy do Ryszarda Wiśniewskiego, dz. cyt., s. 716.

140 S. Świeżawski, Zagadnienie historii filozofii, Wydawnictwo Naukowe Semper, Warszawa 1966, s. 495. 
Bez względu na niektóre braki, poglądy Tatarkiewicza zdają się nie tracić nic na aktualności i wpisywać się we współczesny dyskurs w zakresie relacji pomiędzy filozofią systematyczną a historią filozofii, szczególnie jako odpowiedź na dążenie do usunięcia historii filozofii ze studiów filozoficznych ${ }^{141}$. Odpowiedź, jaką dał Tatarkiewicz na zarzuty Schopenhauera o odtwórczym charakterze historii filozofii, należycie uzasadnia wartość historii filozofii dla samej filozofii ${ }^{142}$ i filozofii dla historii filozofii i historii ludzkości w ogóle. Tym bardziej że jak zwraca uwagę B. Russell:

Aby zrozumieć historyczną epokę czy naród, musimy zrozumieć jego filozofię; aby jednak zrozumieć jego filozofię, musimy być już do pewnego stopnia filozofami. Związki przyczynowe przebiegają tu w obu kierunkach: warunki, w jakich żyją ludzie, determinują w znacznej mierze filozofię, ale zachodzi tu również odwrotna zależność - filozofia, którą wyznają, w poważnym stopniu determinuje warunki życia ${ }^{143}$.

\section{Bibliografia}

Albert K., Studia o historii filozofii, tłum B. Baran, J. Marzęcki, Fundacja Aletheia, Warszawa 2006.

Brożek A., Będkowski M., Chybińska A., Ivanyk S., Traczykowski D., Antyirracjonalizm. Metody filozoficzne w Szkole Lwowsko-Warszawskiej, Wydawnictwo Naukowe Semper, Warszawa 2020.

141 „Dla wielu historia filozofii przedstawia się jako «krótkie wprowadzenie do ludzkiej głupoty», trwającej do czasów Russella, Ludwiga Wittgensteina i Heideggera. Skoro zaś już raz przez ową epokę przebrnęliśmy, to nie ma powodów, by zagłębiać się ponownie w błędy przeszłości” R.H. Popkin, Filozofia a historia filozofii, w: Historia filozofii zachodniej, red. R.H. Popkin, Zysk i S-ka, Poznań 2003, s. 778.

142 „Próbuje się przeto zadzierzgnąć więź między badaniami nad historią filozofii a samą merytoryczną filozofią. Wielu historyków filozofii podkreśla z tego powodu, że uprawianie historii filozofii służy zarazem sprawie filozofii”. K. Albert, Studia o historii filozofii, tłum B. Baran, J. Marzęcki, Fundacja Aletheia, Warszawa 2006, s. 5.

143 B. Russell, Dzieje filozofii zachodu, tłum. T. Baszniak, A. Lipszyc, M. Szczubiałka, Fundacja Aletheia, Warszawa 2000, s. 10. 
Dembowski B., Wspomnienia uczestnika seminarium prowadzonego przez prof. Władysława Tatarkiewicza w latach 1947-1950, w: Władysław Tatarkiewicz $w$ siedemdziesięciolecie I wydania „Historii Filozofii”, red. C. Głombik, Gnome, Katowice 2003, s. 24-39.

Handelsman M., Historyka, Neriton, Warszawa 2010.

Jadacki J.J., Metodologia w ujęciu Władysława Tatarkiewicza, w: Władysław Tatarkiewicz w siedemdziesięciolecie I wydania „Historii Filozofii”, red. C. Głombik, Gnome, Katowice 2003 s. 77-89.

Kleszcz R., W. Tatarkiewicz. Uwagi metafilozoficzne, „Zagadnienia Naukoznawstwa" 2017, 1(211).

Kotarbińska J., Definicja w: tejże, $Z$ zagadnień teorii nauki i teorii języka, Państwowe Wydawnictwo Naukowe, Warszawa 1990, s. 128-151.

Kotarbińska J., Tak zwana definicja deiktyczna. w: tejże, $Z$ zagadnień teorii nauki i teorii języka, Państwowe Wydawnictwo Naukowe, Warszawa 1990, s. 245-281.

Kuderowicz Z., Przegląd metod historii filozofii, Zakład Narodowy im. Ossolińskich, Wrocław 1978.

Kuderowicz Z., Czy „Historia filozofii” należy do humanistyki rozumiejącej?, w: Władysław Tatarkiewicz w siedemdziesięciolecie I wydania Historii Filozofii, red. C. Głombik, Gnome, Katowice 2003.

Nowik A.M., Historiografia Władysława Tatarkiewicza w kontekście sporów metodologicznych, „Filo-Sofija” 2011, nr 13-14(2-3).

Palacz R., W. Tatarkiewicz jako historyk filozofii. Kilka uwag, „Filo-Sofija” 2011, nr 13-14(2-3).

Popkin R.H., Filozofia a historia filozofii w: Historia filozofii zachodniej, red. R.H. Popkin, Zysk i S-ka, Poznań 2003.

Russell B., Dzieje filozofii zachodu, tłum. T. Baszniak, A. Lipszyc, M. Szczubiałka, Fundacja Aletheia, Warszawa 2000.

Świeżawski S., Zagadnienie historii filozofii, Wydawnictwo Naukowe Semper, Warszawa 1966.

Tatarkiewicz W., Skupienie i marzenie, Wydawnictwo M. Kot, Kraków 1951.

Tatarkiewicz W., Pisma zebrane, Droga do filozofii i inne rozprawy filozoficzne, t. I, Państwowe Wydawnictwo Naukowe, Warszawa 1971.

Tatarkiewicz W., Parerga, Państwowe Wydawnictwo Naukowe, Warszawa 1978. 
Tatarkiewicz W., Układ pojęć w filozofii Arystotelesa, tłum. I. Dąmbska, Państwowe Wydawnictwo Naukowe, Warszawa 1978.

Tatarkiewicz W., Zapiski do autobiografii w: Teresa i Władysław Tatarkiewiczowie, Wspomnienia, Państwowy Instytut Wydawniczy, Warszawa 1979.

Tatarkiewicz W., Dzieje sześciu pojęć, Państwowe Wydawnictwo Naukowe, Warszawa 1982.

Tatarkiewicz W., O filozofii i sztuce, Państwowe Wydawnictwo Naukowe, Warszawa 1986.

Tatarkiewicz W., O szczęściu, Państwowe Wydawnictwo Naukowe, Warszawa 2003.

Tatarkiewicz W., Listy do Ryszarda Wiśniewskiego, oprac. R. Mordarski, „Filo-Sofija", nr 13-14(2-3).

Twardowski K., Myśl, mowa i czyn, red. A. Brożek, J. Jadacki, Copernicus Center Press, Warszawa 2014.

Twardowski K., Wybrane pisma filozoficzne, Państwowe Wydawnictwo Naukowe, Warszawa 1965.

Artykuł powstał $\mathrm{w}$ ramach projektu nr 2015/18/E/HS1/00478, finansowanego przez Narodowe Centrum Nauki.

\section{Streszczenie}

$\mathrm{W}$ artykule stawiam sobie za cel rekonstrukcję poglądów Tatarkiewicza z zakresu metodologii ogólnej przy użyciu metody interpretacji twórczej Kazimierza Twardowskiego, wraz z uzupełnieniem tejże o rekonstrukcję jego poglądów z zakresu metodologii historii i historii filozofii, po to by nadać tym poglądom organiczny charakter, którego dotąd nie otrzymały. Ostatecznie będę argumentował za stawianą tezą o opisowym i eklektycznym charakterze poglądów historiograficznych Tatarkiewicza oraz niektórych brakach jego metodologii historii i historii filozofii.

Słowa kluczowe: Władysław Tatarkiewicz, metodologia, klasyfikacja nauk, klasyfikacja, typologizacja, metody historyczne, metodyka pracy pisarskiej 


\section{Summary}

\section{Władysław Tatarkiewicz’s Methodology}

In this article, I aim to reconstruct the views of Tatarkiewicz in the field of general methodology using the creative interpretation method of Kazimierz Twardowski, supplementing it with the reconstruction of his views on the methodology of history and the history of philosophy, in order to give these views an organic character which it has lacked till now. Ultimately, I will argue for the thesis put forward, about the descriptive and eclectic nature of Tatarkiewicz's historiographic views and about some shortcomings in his methodology of history and the history of philosophy.

Key words: Władysław Tatarkiewicz, methodology, classification of sciences, classification, typologization, historical methods, methodology of writing work 